\title{
Misapplied names, synonyms and new species of Ipomoea (Convolvulaceae) from South America
}

\author{
John R. I. Wood ${ }^{1,2} \&$ R. W. Scotland ${ }^{1}$
}

Summary. The identities of plants treated under the names Ipomoea goyazensis Gardner, I. bignonioides Sims, I. patula Choisy, I. fiebrigii Hassl. ex O’Donell, I. hirsutissima Gardner and I. carajasensis D. F. Austin are evaluated. It is shown that the name I. goyazensis should be used for the cerrado species often known under the name I. decora Meisn., rather than a plant from southern Brazil which is here described as a new species I. austrobrasiliensis J. R. I. Wood \& Scotland. I. bignonioides Sims is synonymised with I. mauritiana Jacq., and an epitype is selected to fix the application of this name and ensure it is not confused with I. goyazensis. I. patula is lectotypified and treated as a synonym of the African I. crassipes Hook. The different recognised varieties of $I$. patula are evaluated; var. monticola Meisn. is treated as a species under the name I. langsdorffi Choisy; var. villosa Meisn. is shown to be a synonym of $I$. guaranitica Chodat \& Hassl., in which is included the little-known species I. cornucopia Chodat \& Hassl. Specimens from Paraguay, originally also treated as I. patula var. villosa or I. malvaeoides Meisn. var. ovata Hallier f., are treated as a distinct species named I. cordillerae J. R. I. Wood \& Scotland. Plants from Brazil treated in various herbaria under the name of the Paraguayan species I. fiebrigii are shown to be a distinct species, which is described as new under the name I. angustissima J. R. I. Wood \& Scotland. Species sometimes included in I. hirsutissima are discussed and a key to distinguish them is provided. I. pyrenea Taub. is illustrated and shown to be distinct and a plant from Paraguay sometimes named I. hirsutissima is described as new under the name I. megalantha J. R. I. Wood \& Scotland. I. carajasensis D. F. Austin is shown to be a synonym of I. maurandioides Meisn. and plants from the cerrados of central Brazil often identified as this species are described as new under the name I. aequiloba J. R. I. Wood \& Scotland. Two other commonly misunderstood species I. elegans A. Dietr. and I. serpens Meisn. are also discussed. All new species and some little-known species are illustrated, maps of contrasting distributions are provided and various lectotypifications are made to fix the concepts of several species discussed in this paper.

Key Words. Argentina, Brazil, cerrado, illustrations, misidentification, Paraguay, synonyms, taxonomy, typification.

\section{Introduction}

During the course of our work in preparing a monograph of the genus Ipomoea L., we have become aware of a number of South American names which are misinterpreted in herbaria and the literature. This is partly a consequence of the near absence of taxonomic, as opposed to nomenclatural, publications on South American species since the series of papers published by O'Donell (1948, 1950a, 1950b, 1952, 1953, 1959a, 1959b, 1960 inter alia). Since then only the occasional paper describing new species has been published apart from the flora accounts prepared by Dan Austin for Ecuador (Austin 1982a), Venezuela (Austin 1982b) and the Guiana Highlands (Austin 1998). A recent paper by Austin et al. (2015) has formalised and compounded a number of these misinterpretations and this paper aims to clarify and correct the most important of these.

\section{Materials and Methods}

This paper is based primarily on the study of the relevant literature cited in the list of references and a range of specimens which we have seen in different herbaria in Brazil, the United States and Europe. We have made free use of type images and the reproductions of old, somewhat obscure publications available through Jstor (www.jstor.org/), which have proved very useful in the preparation of this paper. We have made regular use of other online data bases and their images, especially those of Tropicos (www.tropicos.org/), Reflora (www.herbariovirtualreflora.jbrj.gov.br/), neotropical herbarium specimens at the Field Museum (fm1.fieldmuseum.org/) and the New York Botanical Garden (sciweb.nybg.org/). We have consulted the Convolvulaceae in the Catalogus Hasslerianus (Ramella 2010) but draw readers' attention to the fact that the names in this catalogue are not necessarily published names but represent the names under which the plant is kept in the Geneva

Accepted for publication 7 February 2017. Published online 24 March 2017

1 Department of Plant Sciences, University of Oxford, South Parks Road, Oxford, OX1 3RB, UK. e-mail: robert.scotland@plants.ox.ac.uk

2 Royal Botanic Gardens, Kew, Richmond, Surrey, TW9 3AB, UK. 
herbarium (Ramella 2010: 14). Our comments and reasoning are set out under the headings of the main species we discuss.

\section{The identity of Ipomoea goyazensis Gardner}

There has been uncertainty about the application of this name for many years. The species was described by Gardner in 1842 but was included in Ipomoea batatoides Choisy as a synonym of I. batatoides var. angulata Choisy by Choisy (1845) in De Candolle's Prodromus. Meisner (1869) in Flora Brasiliensis, however, accepted I. goyazensis as a distinct species and included it within a group characterised as having "folia cordata, pedunculi brevissimi (saltem folio breviores), pauci - 1-flori”, in which he also described I. decora Meisn., thus implying they were different species. He did not, however, compare the two and no one seems to have done this over the next 80 years. However, in the 1950 s it seems, from his herbarium determinations, that O'Donell had come to regard I. goyazensis and I. decora as conspecific and treated both under the older name $I$. goyazensis, an opinion with which we agree.

There is no dispute as to the identity of Ipomoea decora, of which there is a type specimen (Pohl s.n.) at $\mathrm{K}$ and $\mathrm{OXF}$, and an illustration in Flora Brasiliensis. In recent years this name has generally been used for the cerrado species from central Brazil which is characterised by a compact inflorescence with very short peduncles and pedicels (Fig. 1), whereas the name $I$. goyazensis has been applied to a quite different species from the Atlantic forest regions of southern Brazil characterised by a lax inflorescence with long peduncles and pedicels (Fig. 2). This interpretation appears to have arisen from Choisy's decision to unite I. goyazensis with I. batatoides var. angulata treating it as one of the syntypes of this variety. The other syntype, Martius s.n, (M0184900), clearly represents the species from the south of Brazil but the implication (Austin et al. 2015: 631, note 3) that Choisy's disposition of the specimens at Munich (M) is critical to the typification of I. goyazensis is erroneous. I. goyazensis was described by Gardner some two years earlier and Choisy's comments are only relevant to the typification of I. batatoides var. angulata.

The specimen cited as the type of Ipomoea goyazensis, Gardner 3909, could not be found at K, $\mathrm{BM}$ or OXF and may have been lost after the preparation of the plate in Hooker's Icones Plantarum so the only possible type is this image. This is quite clearly not the same as Martius s.n. at Munich, the type of I. batatoides var. angulata, but is a quite reasonable representation of the cerrado plant usually treated today as $I$. decora. This is confirmed by examination of the protologue which describes the peduncles as short, three-flowered and the corolla having a white tube but violet limb, exactly fitting the cerrado plant (Fig. 1). Even more convincing is the type locality (Serra de Santa Brida) from northern Goiás around $12^{\circ} 30^{\prime} \mathrm{S} 47^{\circ} 15^{\prime} \mathrm{W}$. This is well within the known range of this species but far from southern Brazil where I. batatoides var. angulata grows. (Map 1). We thus concur with O'Donell that I. goyazensis is the correct name for the plant often identified as I. decora and that a name at specific rank is required for I. batatoides var. angulata. The two species with their synonomy are set out below:

Ipomoea goyazensis Gardner, Icon. Pl. 5: t. 479 (1842). Type: Brazil. Goiás, Serra de Santa Brida. Type: Plate 479 in Hooker, Icon. Pl. 5 (1842), lectotype, designated here).

Ipomoea decora Meisn. (Meisner 1869: 272). Type: Brazil. Goiás, Pohl 1760 (possible isotypes K000612854!, OXF!).

HABITAT \& DISTRIBUTION. Ipomoea goyazensis is widespread but apparently uncommon in cerrado or carradão over a wide range (Map 1) but is unknown from the cerrados in the south of Brazil or north of the Amazon. We have seen specimens from Eastern Bolivia in Velasco Province [Killeen et al. 5399 (ARIZ, $\mathrm{MO}$ ), Wood et al. 27806 (K, LPB, OXF, USZ) and in Brazil from the states of Ceará, [A. Löfgren 131 (S), 318 (S)], Goiás [D. Alvarenga et al. 788 (CEN, MO), Pastore 3078 (HUEFS)], Maranhao [Schatz et al. 793 (K), Gardner 6070 (BM, K)], Mato Grosso [W. D. Sasaki et al. $1862(\mathrm{~K})$ ], Minas Gerais [A. Macedo 1668 (BM, MO)], Pará [Aubréville 190 (P), Plowman et al. 9706 (MG, MO); da Silva 1786 (MG, MO)], Rondonia [N. C. Bigio et al. 1020 (RB)] and Tocantins [da Silva et al. 3995 (IBGE, MO, RB)].

NOTES. Plants are usually \pm glabrous but hirsute forms (Pastore 3078) occur rarely and there is some variation in the size of the sepals.

Ipomoea austrobrasiliensis J. R. I. Wood E S Sotland, sp. nov. Type: Brazil, Paraná, Mun. Paranagua, Pico Torto, 15 Jan. 1970, G. Hatschbach 23340 (holotype $\mathrm{MBM}$ !; isotypes $\mathrm{F}$ !, $\mathrm{K}$ !).

http:/ /www.ipni.org/urn:lsid:ipni.org:names:77159998-1

Ipomoea batatoides var. angulata Choisy (1845: 376). Type: Brazil, São Paulo, Martius s.n. (lectotype M0184900!, designated here), non Ipomoea angulata Lam. Ipomoea goyazensis auct. sensu Austin et al. 2015: 627.

Vigorous climbing perennial of unknown height, glabrous in all parts. Leaves petiolate, generally large, $10-$ $22 \times 9-16 \mathrm{~cm}$, ovate, cordate with rounded auricles, 


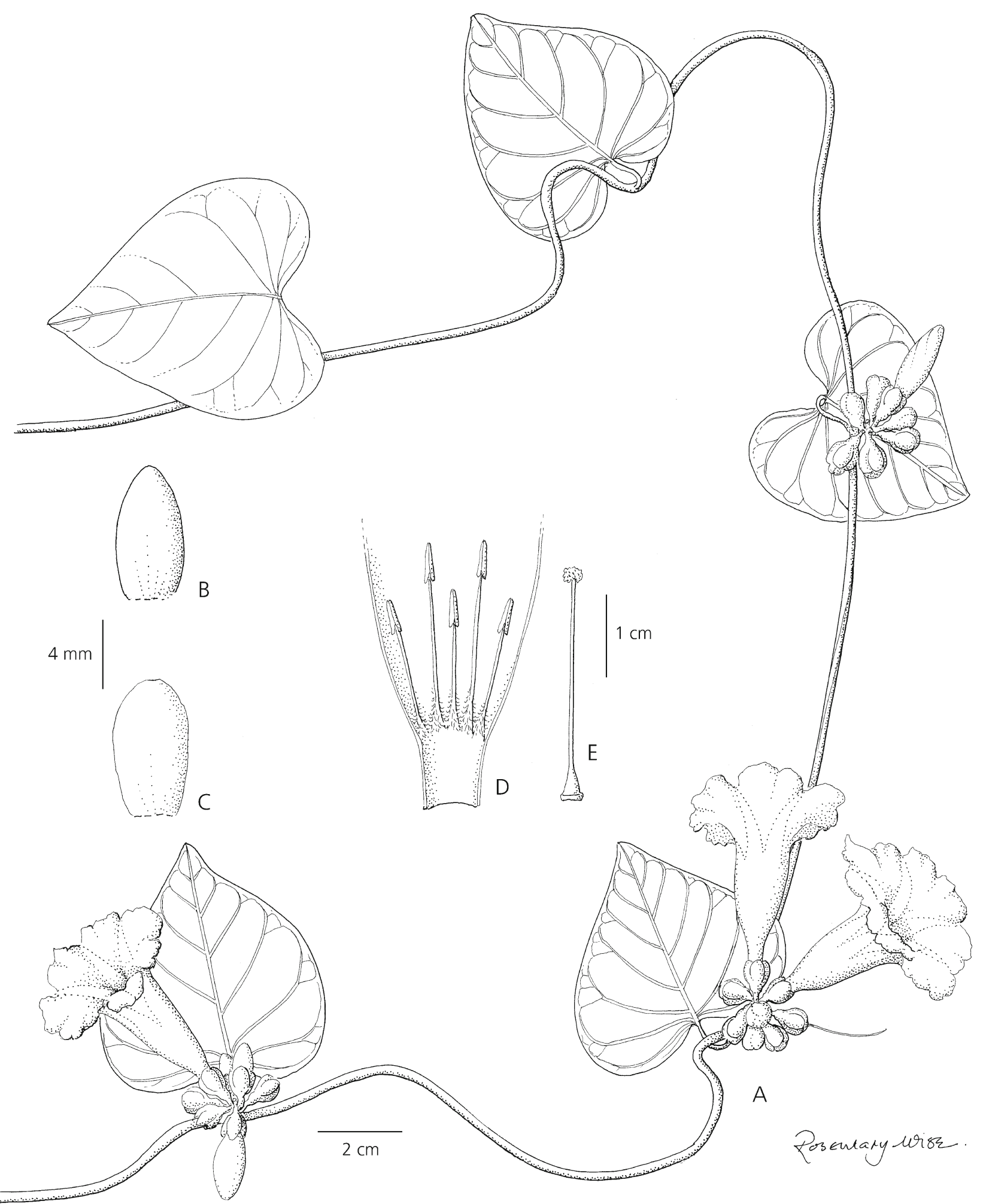

Fig. 1. Ipomoea goyazensis. A habit; B outer sepal; C inner sepal; D corolla opened out to show stamens; E ovary and style. From Wood et al. 27806. DRAWN BY ROSEMARY WISE.

apex acute to shortly acuminate, margin slightly undulate to subsinuate, sometimes with a distinct tooth above the auricle, glabrous on both surfaces but abaxially paler with prominent venation, the main veins with distinct pale margins; petioles $8-16 \mathrm{~cm}$. Inflorescence of lax, axillary pedunculate cymes; pedun- 


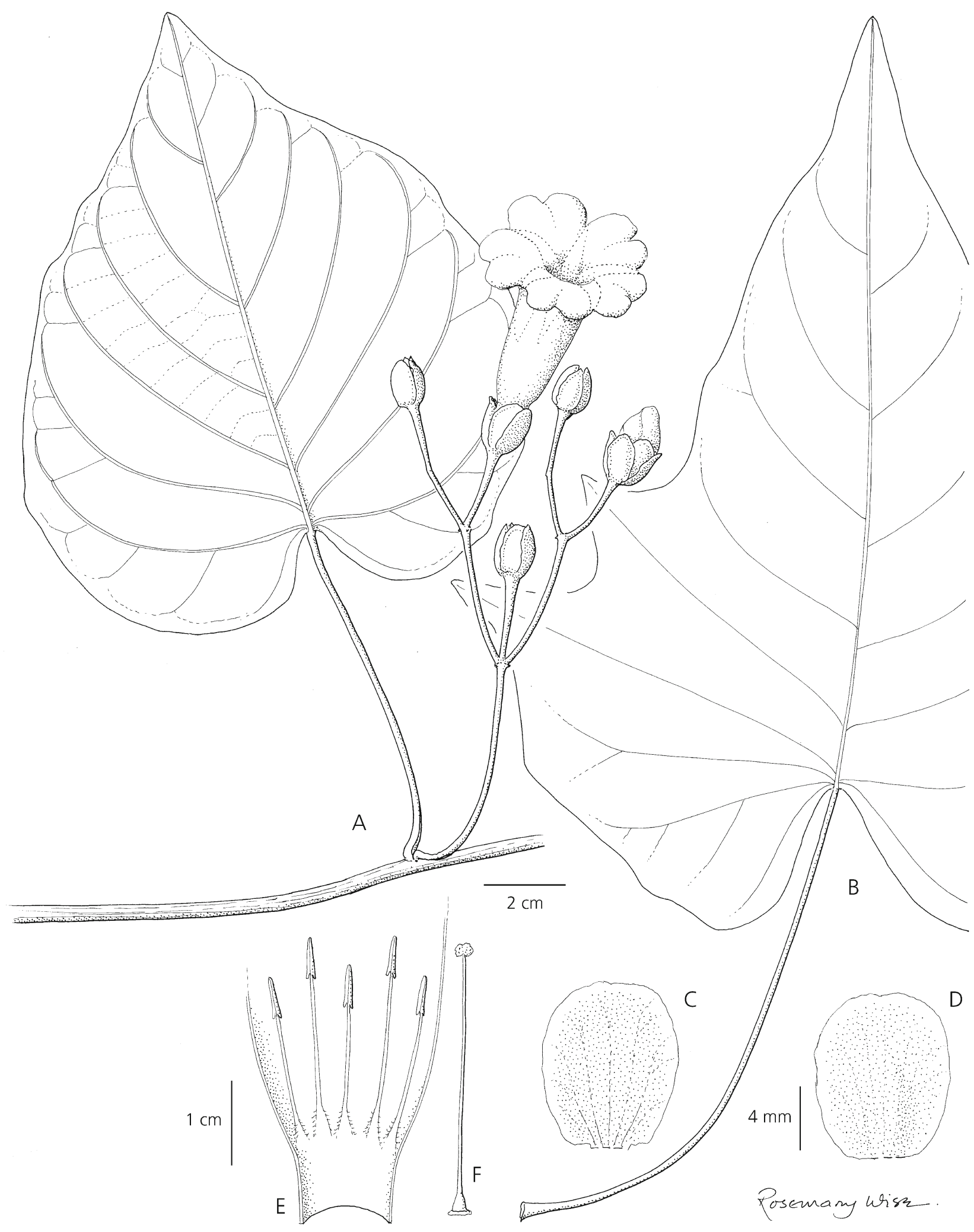

Fig. 2. Ipomoea austrobrasiliensis. A habit; B leaf; C outer sepal; D inner sepal; E corolla opened out to show stamens; F ovary and style. A, C - F from Reitz \& Klein 6615; B from Reitz \& Klein 4102. DRAWN BY ROSEMARY WISE. 
cles $3-10 \mathrm{~cm}$, bracteoles $1-3 \mathrm{~mm}$, linear-oblong, caducous, margins scarious; secondary peduncles 2 $3.5 \mathrm{~cm}$; tertiary peduncles (if present) c. $1.5 \mathrm{~cm}$; pedicels $10-18 \mathrm{~mm}$, thickened upwards; sepals subequal, coriaceous, concave, rounded, outer $9-10$ $\times 6-7 \mathrm{~mm}$, obovate, inner slightly wider, broadly elliptic with scarious margins; corolla $4.5-5.5 \mathrm{~cm}$ long, narrowly funnel-shaped, tube pale, limb deep pink, somewhat lobed, c. 4 cm diam.; stamens included; filaments glabrous except for pubescent bases, unequal, shorter 12 - $13 \mathrm{~mm}$, longer 15 - 18 $\mathrm{mm}$, anthers $3.5-4 \mathrm{~mm}$ long; ovary glabrous, style 2.5 - $2.8 \mathrm{~cm}$ long, glabrous. Capsule and seeds not seen. Fig. 2.

RECOGNITION. Distinct from Ipomoea goyazensis because of the lax inflorescence having branched, well-developed cymes with peduncles $3-10 \mathrm{~cm}$ long (not $0.1-0.6 \mathrm{~cm}$ ), pedicels $10-18 \mathrm{~mm}$ (not $0-7 \mathrm{~mm})$ and large leaves $10-22 \times 9-16 \mathrm{~cm}$ (not $4-12 \times 3-10 \mathrm{~cm}$ ) (Figs $1-2$ ). From I. batatoides it is distinguished by the longer sepals and larger leaves which are undulate and often somewhat angled, hence Choisy's varietal name angulata. It might also be confused with the rare glabrous forms of $I$. bonariensis Hook. but these are usually distinguishable by their smaller, differentshaped leaves and moderately compact inflorescences. It is perhaps most similar to I. volcanensis O’Donell from middle altitude $( \pm 2000 \mathrm{~m})$ Andean forest in northern Argentina and southern Bolivia.
From this species I. austrobrasiliensis can be distinguished by its smaller corolla, $<5.5 \mathrm{~cm}$ long (not $>$ $7 \mathrm{~cm}$ ), and strongly cordate rather than subtruncate leaves.

HABITAT \& DISTRIBUTION. Moist Atlantic Forest at low altitudes in São Paulo, Paraná and Santa Catarina States in southern Brazil. Map 1.

SPeCIMenS eXAMINed. BRAZIL. São Paulo: Martius s.n. (M). Paraná: Iacarehy, 25 March 1911, P. Dusen 11400 (GH, K, MICH, S); ibid., P. Dusen 11595 (S); Mun. Guaratuba, Serra do Araraquara, Morro do Cauvi, 100 m, 25 March 1965, G. Hatschbach 12402 (MGM); Mun. Paranagua, Pico Torto, 15 Jan. 1970, G. Hatschbach 23340 (F, K, MBM); Mun. Paranagua, Picadão Cambará - Col. Limeira, 50 m - 100 m, 14 Feb. 1968, G. Hatschbach 18597 (MBM). Santa Catarina: Pinhal da Companhia Lauro Müller Urussanga, 300 m, Reitz E Klein 4102 (US); Tres Barrasm Garuva, São Francisco do Sul, 50 m, 26 March 1958, Reitz Ẽ Klein 6615 (US).

CONSERVATION STATUS. This species occupies a narrow belt of forest country lying behind the east coast of Brazil. Brazil's Atlantic forests are being fragmented and destroyed and we have seen no recent record from São Paulo State. It is highly likely, therefore, that this species will be classified as at least Endangered (EN) within IUCN (2012) guidelines after careful study but we have no data to support this assertion. The number and size of the populations of this species are entirely unknown and we do not have any information about

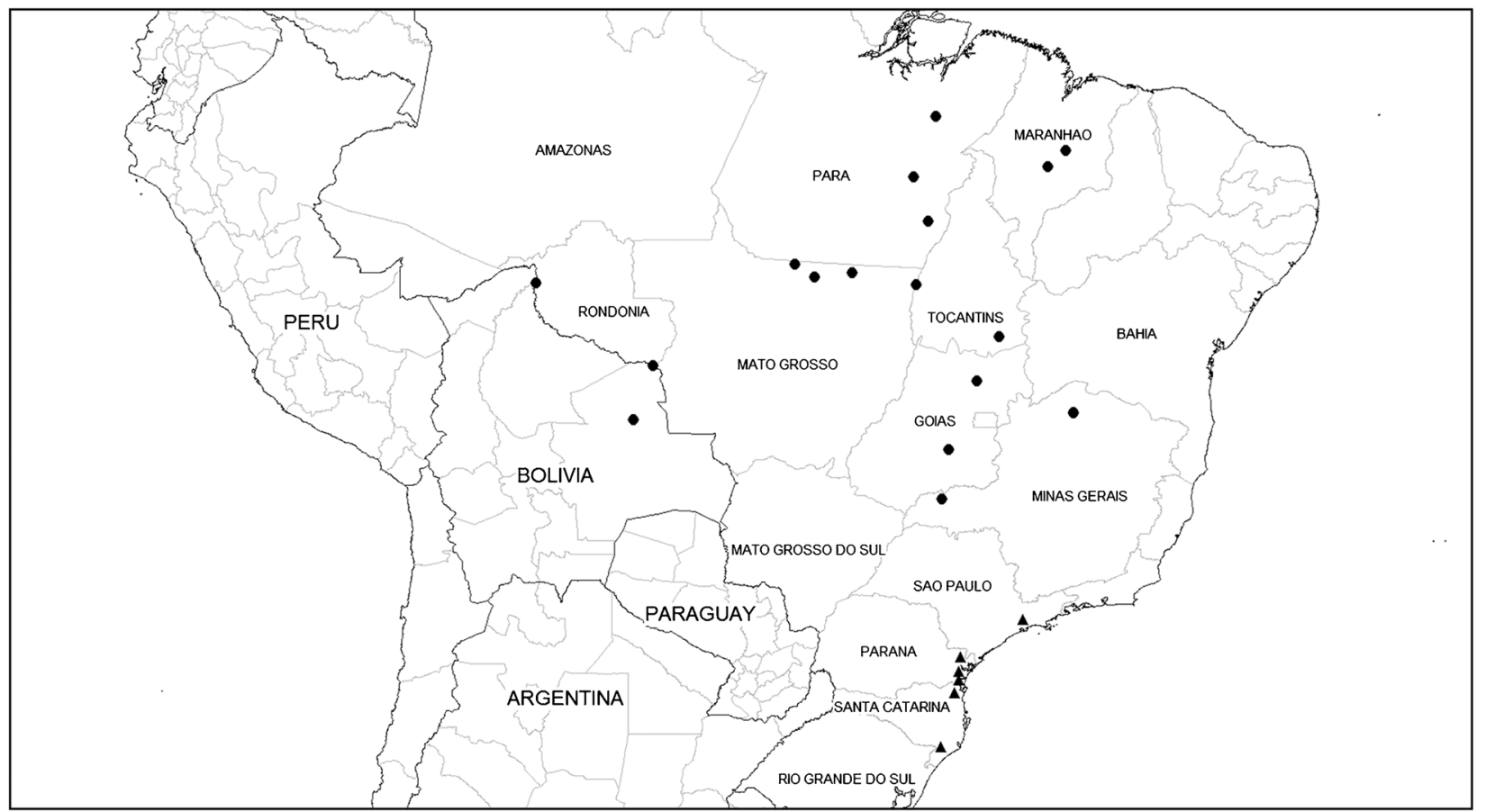

Map 1. Map of Brazil and neighbouring countries showing the distribution of Ipomoea goyazensis $(\bullet)$ in the cerrados south of the Amazon region and of $I$. austrobrasiliensis $(\mathbf{\Delta})$ in Atlantic Forest in SE Brazil. 
its ability to colonise secondary bushland or ruderal habitats so for the time it should be classified as Data Deficient (DD).

EPONYMY. The epithet austrobrasiliensis, meaning "south Brazilian," refers to the geographical region in which this species occurs.

\section{Ipomoea bignonioides Sims}

Ipomoea bignonioides Sims was described by Sims (1826) in the Botanical Magazine from a plant cultivated in England from seeds said to have been collected in Cayenne (Guyane Française). It is clear from the protologue that no specimen was retained and so the only possible type is the illustration (Fig. 3). This is somewhat odd showing a brownish corolla colour we have never observed in Ipomoea, an inflorescence with a single flower and 3-lobed leaves. Both Choisy (1845) and Meisner (1869) accepted this as a good species but neither author cited any specimens under this name. In the $20^{\text {th }}$ century some herbarium annotations suggest it could be equated with I. blanchetii Choisy, perhaps because I. blanchetii has 3lobed leaves and similar coriaceous sepals, but I. blanchetii is a species of NE Brazil, not the Guyanas, and always has a branched inflorescence.

In a recent paper Austin et al. (2015) treated this species as a synonym of Ipomoea goyazensis. This has to be an error on several counts. In the first place I. bignonioides is an older name and so should have been taken up in preference to I. goyazensis. More importantly, there is no good reason to believe the two species are conspecific. I. goyazensis has never been collected north of the Amazon (Map 1) and its occurrence in Cayenne is highly improbable. In any case, neither the leaf shape nor the inflorescence fit I. austrobrasiliensis, as I. goyazensis was interpreted in Austin et al. (2015), or I. goyazensis itself. More recently the Flora do Brasil 2020 em construção website when accessed on 19 April 2016, treated I. bignonioides as a distinct from I. goyazensis (as I. decora Meisn.) and showed a distribution restricted to NE Brazil south of the Amazon, far from Cayenne. The photograph on the website shows a plant with entire leaves and a cymose inflorescence very different from the type of I. bignonioides. Whether this plant is distinct from I. goyazensis is unclear but it cannot be equated with I. bignonioides.

It is, however, possible to infer the identity of Ipomoea bignonioides with some degree of certainty. Assuming its stated origin is correct, the only possible candidate species are I. mauritiana Jacq. and I. batatoides Choisy; both species occur in the Guyanas and both have the distinctive coriaceous sepals clearly visible in the illustration of I. bignonioides. I. batatoides is, however, very improbable as this species nearly always has unlobed leaves. Examination of material of
I. mauritiana from the Guyanas reveals this species to be much the most probable candidate. One of the syntypes of Batatas edulis var. platanifolia Choisy (Schomburgk 701), a synonym of I. mauritiana, is represented at Kew by three sheets, one of which, K000768180 shows almost exactly the same inflorescence as the plate in the Botanical Magazine as well as 3-lobed and 5-lobed leaves (Fig. 4). In order to fix the identity of $I$. bignonioides we propose to select this specimen as an epitype of I. bignonoiodes, which we, therefore, treat as a synonym of I. mauritiana. It should be noted that the BM duplicate of Schomburgk 701 with the original label and the OXF duplicate are very similar to the epitype.

Ipomoea mauritiana Jacq. (Jacquin 1790 [publ. 1791]: 216). Type: plant cultivated in Vienna, probably not preserved.

Ipomoea bignonioides Sims (1826: t. 2645). Type: Icon, t. 2645 in Bot. Mag., epitype, designated here, Schomburgk 701 (sheet K000768180, excluding G. R. M. Pollard 5 with barcode K000766181, mounted on the same sheet).

Convolvulus bignonioides (Sims) Spreng. (Sprengel 1827: 60).

Apopleumon bignonioides (Sims) Raf. (Rafinesque 1838 [1836]: 72).

Batatas bignoniodes (Sims) G. Don (1838: 261).

Batatas edulis var. platanifolia Choisy (1845: 339). Type: Guyana, Schomburgk 701 (isotypes BM, BR, K, OXF). Ipomoea digitata var. quinquefida Meisn. (Meisner 1869: 278). Type: Guyana, Schomburgk 701, lectotype BR0000530737!, chosen here, isolectotypes BM!, K000768180!, OXF!).

\section{The identity of Ipomoea patula Choisy}

There is some uncertainty about the application of this name, which has only occasionally been used for South American plants (Meisner 1869; Hallier 1899; Chodat \& Hassler 1905). It was resurrected by Austin \& Simão-Bianchini (1998) but it has remained generally unused, with no specimens cited, for example, in Tropicos (www.tropicos.org/) although it appears on the Flora do Brasil 2020 em construção website when accessed on 19 April 2016. Following his description of Ipomoea patula (Choisy 1845: 368) cited its locality and type as follows: "In Brasilia. Huic approp. sp. e campis V. Rica prov. Min. Ger. Comm. a cl. Martius obs. No. 788 (v. s. in h. Mus. par)." Following Meisner (1869: 241), the name I. patula has generally been linked to a specimen at Paris (P00434156) while Martius 788 (at M) has been treated as the type of I. patula var. monticola Meisn. (Meisner 1869: 240), subsequently raised to specific rank by O'Donell (1953: 371) as I. monticola (Meisn.) O’Donell. Austin \& SimãoBianchini (1998), however, argued that I. patula Choisy 


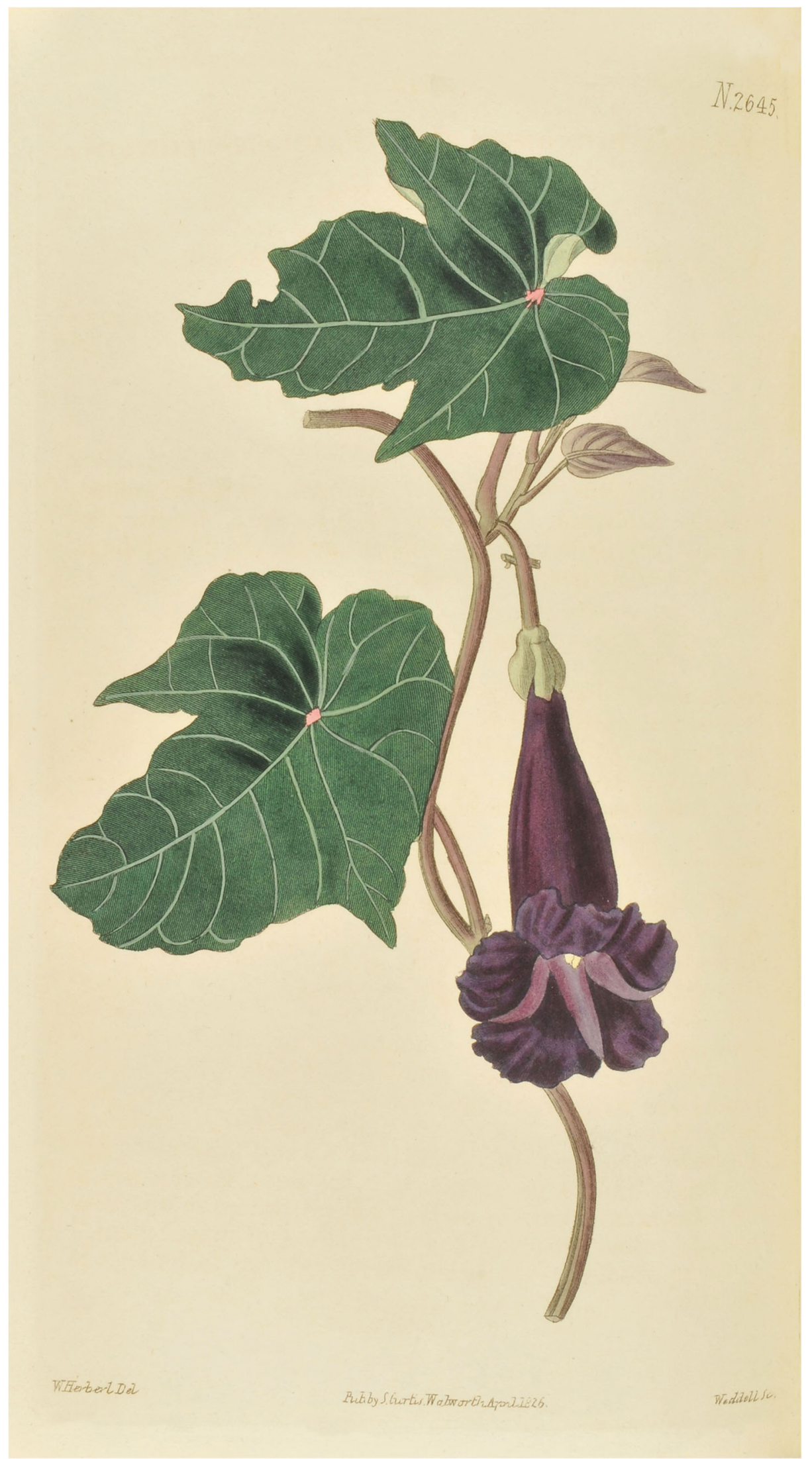

Fig. 3. Ipomoea bignonioides (Botanical Magazine t. 2645). 


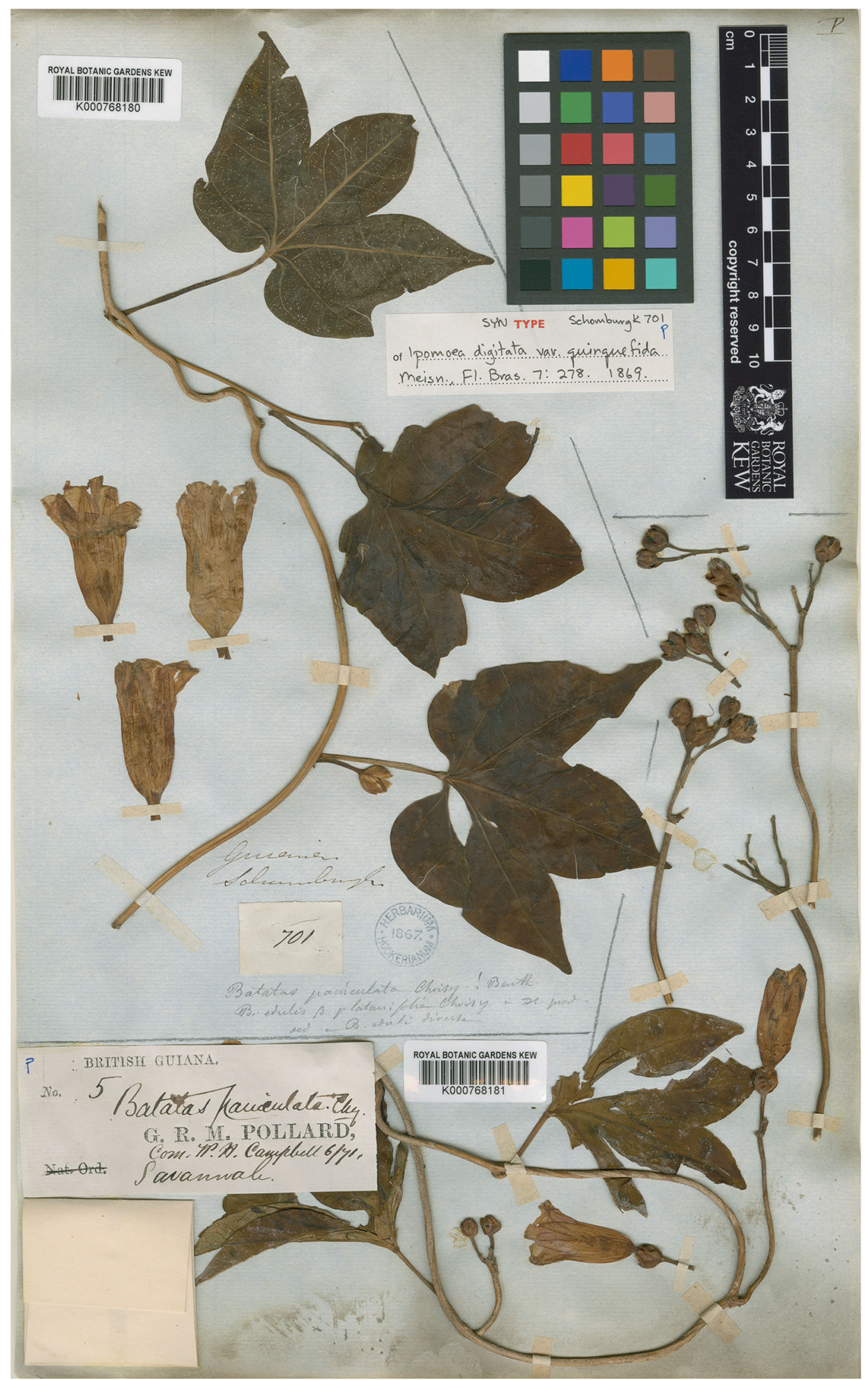

Fig. 4. Epitype of Ipomoea bignonioides, Schomburgk 701 (K000768180) at upper left. OThe Board of Trustees of the Royal Botanic Gardens, Kew. 
was the correct name for I. monticola (Meisn.) O'Donell, suggesting there was a duplicate of Martius 788 at Paris, which would be unlikely and does not appear to be the case. Curiously both I. monticola and I. patula are treated as accepted species in the Checklist of Brazilian Plants (SimãoBianchini \& Ferreyra 2010) and in Flora do Brasil $2020 \mathrm{em}$ construção website when accessed on 19 April 2016.

In order to maintain traditional usage, clarify the situation and, in our opinion, interpret the protologue correctly we are formally designating the specimen at Paris (P00434156) as the lectotype of Ipomoea patula. This specimen which constitutes the original material used by Choisy has no collector's name but is labelled "Brasilia", which is crossed out and relabelled in another hand "Guinea". The specimen actually represents an African plant, identified by Heine as I. crassipes Hook. There can be little doubt that Choisy's description refers to this specimen, rather than Martius 788, which in any case was never apparently housed at Paris, particularly the reference to dimorphic leaves (foliis superioribus oblong-lanceolatis acutis inferioribus ovatis obtusis 10 - 12 lineas longis), the long peduncle exceeding the leaves (pedunculis foliis superantibus) and lanceolate bracteoles (bracteis lanceolatis..). In contrast in Martius 788 the leaves are all clearly similar, the lower leaves much longer than "10 - 12 lineas" and not ovate, the peduncle is much shorter than the subtending leaves and the bracts (bracteoles) are clearly linear, not lanceolate. As the protolgue so clearly fits the Paris specimen, originally labelled "Brasilia", Martius 788 should not be considered as a possible lectotype of I. patula. It does, however, constitute the type of I. monticola which we consider to be a synonym of I. langsdorffii Choisy. This is summarised below:

Ipomoea crassipes Hook. (Hooker 1844: t. 4068). Type: South Africa, Magaliesberg, Burke 177 (neotype K, designated by Meeuse 1958: 730).

Ipomoea patula Choisy (1845: 368), synon. nov. Type:

"Brasilia" (almost certainly Africa), sin. data (lectotype P00434156!, designated here).

DISTRIBUTION. Southern and eastern Africa.

Ipomoea langsdorffii Choisy (1845: 368). Type: Brazil, "Rio Janeiro", Langsdorff s.n. (holotype P03560903!). Ipomoea patula Choisy var. $\beta$ monticola Meisn (Meisner 1869: 240). Type: Brazil, Minas Gerais, Vila Rica, Martius obs. 788 (holotype M0185028!).

Ipomoea monticola (Meisn.) O'Donell (1953: 371). Ipomoea elegans Meisn. (Meisner 1869: 244), nom. illeg. non A. Dietrich (1836: 313). Type: Brazil, Minas Gerais, 1845 (Widgren 309 (lectotype BR00000583768, designated here, isolectotype S12-2113).

DISTRIBUTION. Ipomoea langsdorffii is an infrequently collected species from the cerrados of central Brazil with confirmed records only from Minas Gerais - we would regard the cited location of Rio de Janeiro given by Langsdorff as unlikely. Few specimens of this species were cited by O'Donell (1953) and not all specimens listed in the Reflora virtual herbarium (www.herbariovirtualreflora.jbrj.gov.br/) are correctly named so this species is illustrated and all specimens we have seen are cited below:

SPECIMENS EXAMINED. BRAZIL. "Rio de Janeiro", Langsdorff s.n. (P). Minas Gerais: Vila Rica, Martius obs. 788 (M); sin. loc., F. Sello(w) 678 (B十, photo F); sin. loc., Widgen 309 (BR, S); ibid., 1840, Clausen s.n. BM); ibid., 1844, Weddell 1912 (P); San Francisco, Nov. 1843, Weddell 1175 (P); Lapa, prope Serra da Pieda, Warming s.n. (BR); Mun. Bello Horizonte, Villa Cruzeiro do Sul, 28 Dec. 1932, Mello Barreto 2312 (F, LIL, RB); Mun. Betim, Contagem, Faz. do Cabuí, 900 m, Feb. 1945, L. O. Williams 5101 (GH); 3 km de Paraopeba, Faz. de Chico Mauricio, 9 Feb. 1957, E. P. Heringer 5492 (UB); Serra do Itabirito, $45 \mathrm{~km}$ SW of Belo Horizonte, 1500 m, 9 Feb. 1968, H. S. Irwin et al. 19706 (FTG); Mun. Ouro Preto, Sto. Antonio do Leite, 27 Feb. 1978, J. Badini 2969 (HUEFS, OUPR).

NOTES. Ipomoea langsdorffi is a densely hirsute, usually trailing herb. The leaves are distinctly petiolate and typically oblong-elliptic. The usually compact, pedunculate axillary cymes with persistent linear bracteoles $12-15 \mathrm{~mm}$ in length are distinctive. Unlike I. guaranitica Chodat \& Hassl., the cymes are usually 3-flowered and with distinct pedicels, the bracteoles distant from the calyx. Fig. 5.

A further issue needs to be dealt with as the result of the assertion in Austin et al. (2015: 628) that Ipomoea elegans A. Dietr., as opposed to I. elegans Meisn., is a synonym of I. patula Choisy. As I. elegans A. Dietr. antedates $I$. patula by almost ten years it would appear that it should be instated as the correct name for the plant treated above as I. langsdorffii. We do not believe this to be the case. Dietrich (1836) diagnosed I. elegans as "foliis inferioribus, quinquelobis, superioribus palmatim-septemlobis utrinque subhirtis scabriusculis, lobis lanceolatis, obtusis ..." None of these statements fit I. langsdorffi, which has simple hirsute leaves. As Dietrich mentions that the plant has been in cultivation for a long time, it seems most likely that I. elegans A. Dietr. is the earlier I. platensis Ker-Gawl, also described from cultivated material, or just possibly I. gigantea Silva Manso or I. malvaeoides Meisn.

\section{Species treated as varieties of Ipomoea patula Choisy}

Meisner (1869) described two other varieties of Ipomoea patula, var. $\gamma$ selloana and var. $\delta$ villosa, both from southern Brazil and both based on collections by Sello $(w)$. We have not traced any possible type of var. $\gamma$ selloana or any specimen that might be considered part 


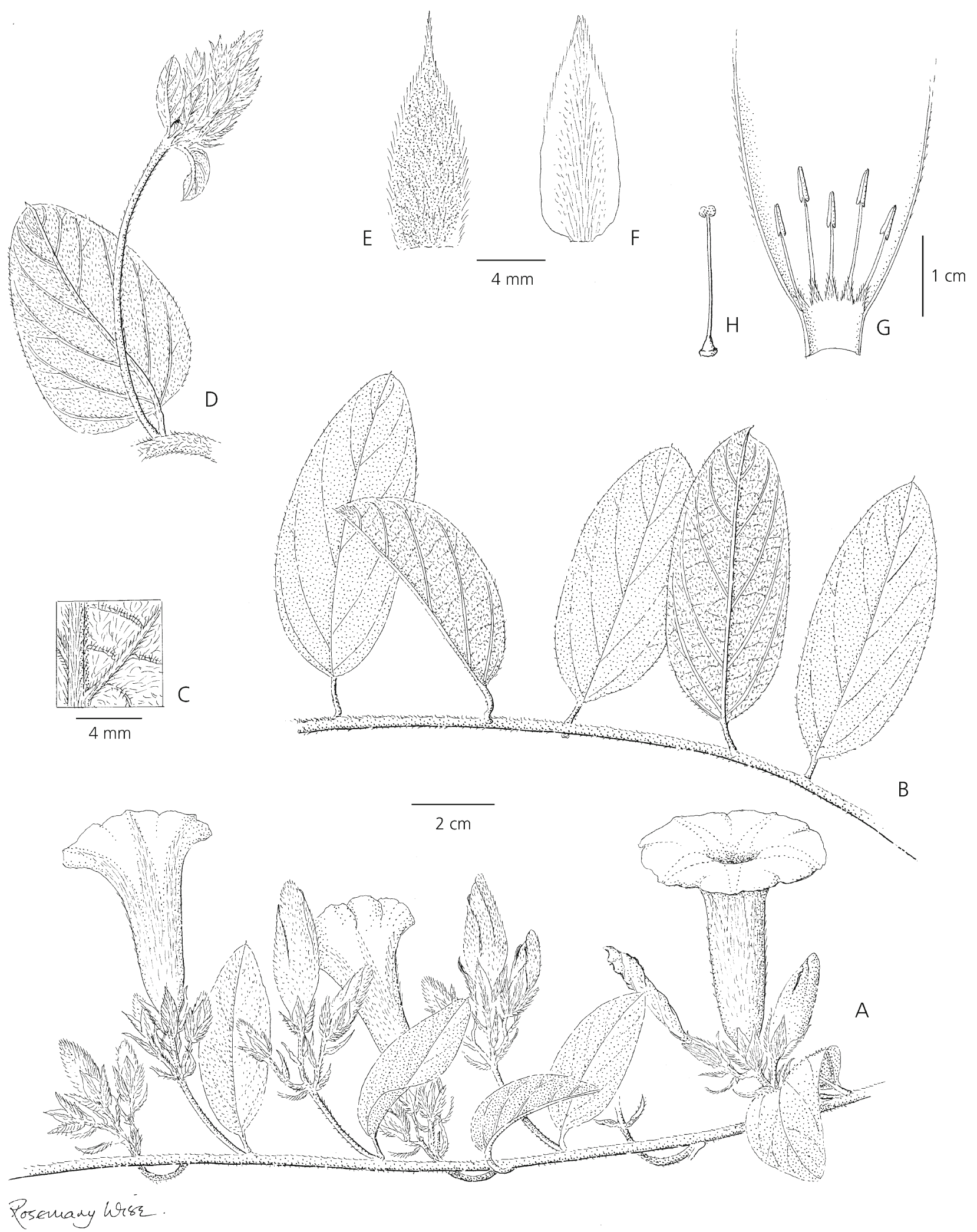

Fig. 5. Ipomoea langsdorfii. A - B habit; C abaxial leaf surface; D peduncle and inflorescence; E outer sepal; F inner sepal; G corolla opened out; H ovary and style. A - C, E - H from Weddell 1912; D from Clausen S.n. DRAWN BY ROSEMARY WISE.

of the original material seen by Meisner so this name remains of uncertain application. However, the pho- tograph of Sellow 5089 at the Field Museum, taken of the specimen at Berlin destroyed in 1943 and labelled 
"Ipomoea patula Chois. $\delta$ villosa Meisn." is of a syntype of var. $\delta$ villosa. In our opinion this is a good match with the plant subsequently described as I. guaranitica by Chodat \& Hassler (1905). This was treated as a synonym of $I$. langsdorffi (under the name I. patula) by Austin et al. 2015 but this is clearly erroneous.

We are also taking the opportunity here to reduce Ipomoea cornucopia to synonymy with I. guaranitica. This species has been confused with I. pseudocalystegia Hassl. but examination of the two sheets at $\mathrm{G}$ shows it to be synonymous with $I$. guaranitica. The sheet without corollas is labelled as having been collected by the Río Capibary on the way to Yerbales in the Sierra de Maracayú, this last being the type location of I. guaranitica. On the sheet with corollas, the label does not mention Yerbales or the Sierra de Maracayú but there is descriptive information, curiously not used in the preparation of the protologue. As the description must have been based mostly on the flowering specimen, this is selected as the lectotype of I. cormucopia. The exact location of Río Capibary is unknown.

Ipomoea guaranitica Chodat $\mathcal{E}$ Hassl. (Chodat \& Hassler 1905: 688). Type: Paraguay, [Dep. Canindeyú], Ipé hú, Yerbales, Sierra de Maracayú, Oct. 1898, Hassler 5008 (lectotype G00174894!, designated here, isolectotypes $\mathrm{BM}$ !, $\mathrm{K}$ !, $\mathrm{NY}$ !, $\mathrm{P}$ !, UC).

Ipomoea patula Choisy var. $\delta$ villosa Meisn. (Meisner 1869: 240), synon. nov. Type: Southern Brazil, Sellow 5089 (photo F of specimen at B destroyed in 1943). Ipomoea cornucopia Chodat \& Hassl. (Chodat \& Hassler 1905: 688), synon. nov. Type: Paraguay, [Dep. Canindeyú (possibly Caazapá, fide Ramella 2010: 62)], Río Capibary, Yerbales de Sierra de Maracayú, Sept. 1898, Hassler 4474 (lectotype G00288030!, designated here).

DISTRIBUTION. Ipomoea guaranitica appears to be widespread but uncommon in eastern Paraguay and southern Brazil as evidenced by the collections cited below. Its exact habitat and frequency are unknown but its habit strongly suggests it is a plant of seasonally burnt grassland.

SPeCimens examined. Paraguay. Dept. Alto Paraná: 1909/10, K. Fiebrig 6037 (GH). Dept. Caaguazú, 6 Nov. 1874, Balansa 1075 (P); Río Yhú, E. Hassler 9510/9510a (BM, G, MO, P). BRAZIL. Paraná: km 127, Laranjeiras do Sul, 5 Dec. 1969, G. Hatschbach et al. 23119 (MO, NY, US). Santa Catarina, $8-13 \mathrm{~km} \mathrm{~W}$ of Chapecó, 16 Dec. 1964, Smith Ẽ Klein 14056 (NY, US).

Rio Grande do Sul: entre Panamba \& Palmeiras, 24 Jan. 1964, Lima 64-4234 (IPA); Neu Württemberg, Palmeraquelle, 7 Dec. 1906, A. Bornmüller 768 (GH). NOTES. Unlike Ipomoea langsdorffi, I. guarantica is an erect herb with very shortly petiolate oblong-oblanceolate leaves $10-14 \mathrm{~cm}$ long. The inflorescence is clearly subterminal, the flowers solitary from the upper leaf axils. They are long-peduculate but with reduced pedicels so the relatively persistent bracteoles lie immediately below the calyx. Fig. 6 .

There is also the issue of the Paraguayan plant treated as Ipomoea patula var. villosa by Hallier (1899: 47) and Chodat \& Hassler (1905: 688). This was redescribed in some detail by Hallier based on three collections (Balansa 1049, Hassler 285 and Hassler 1903). These three collections, however, do not represent the same species.

Balansa 1049 (G, P) differs from Hallier's description in several important ways, notably in having some leaves 3-lobed, and was, in fact, annotated by Hallier in 1892 as Ipomoea patula var. monticola Meisn. It was collected from near Villarrica in Guairá Province, Paraguay and is I. valenzuelensis Chodat \& Hassl.

The redescription appears to have been made using the two Hassler specimens, Hassler 285 and Hassler 1903. These do not represent Ipomoea valenzuelensis, I. guaranitica or I. langsdorffi but another species, which Hallier (1899: 52) described as var. ovata of I. malvaeoides in the same paper. The type of this was Balansa 4391 from Peribebuy in Cordillera Department, precisely the same location from where Hassler 1903 was collected. The three all appear to represent the same species, which is treated as new below:

Ipomoea cordillerae $J$. R. I. Wood E Scotland, nom. et stat. nov.

http:/ /www.ipni.org/urn:lsid:ipni.org:names:60473760-2

Ipomoea malvaeoides var. ovata Hallier f., Bull. Herb. Boissier 7, App. 1: 52 (1899). Type: Paraguay, [Dep. Cordillera] Cordillère de Peribebuy, Balansa 4391 (lectotype G00174792, designated here), non Ipomoea ovata E. Mey. ex Rendle.

Erect subshrub to at least $50 \mathrm{~cm}$; stems woody below, \pm glabrescent; above herbaceous, softly white-tomentose. Leaves very shortly petiolate, $2.4-7 \times 3.2-5 \mathrm{~cm}$, ovate, oblong or oblong-elliptic, acute and mucronate, base broadly cuneate, margin entire, both surfaces softly pubescent, abaxially more densely so, paler, adaxially somewhat glabrescent on very old leaves; petioles $0-4$ $\mathrm{mm}$, densely pubescent to villous. Inflorescence usually of solitary, pedunculate axillary flowers forming a long leafy raceme; occasionally of axillary cymes with up to five flowers from the uppermost leaf axils; bracts leaf-like except the uppermost which are much reduced; peduncles $0.8-4 \mathrm{~cm}$, densely white-pubescent; bracteoles $6 \mathrm{~mm}$ long, linear filiform; pedicels $0.6-7 \mathrm{~cm}$, densely pubescent; sepals with a dark gland near base, somewhat unequal, outer $9-15 \times 2-4 \mathrm{~mm}$, narrowly ovate, acuminate or acute and mucronate, tomentose, inner 


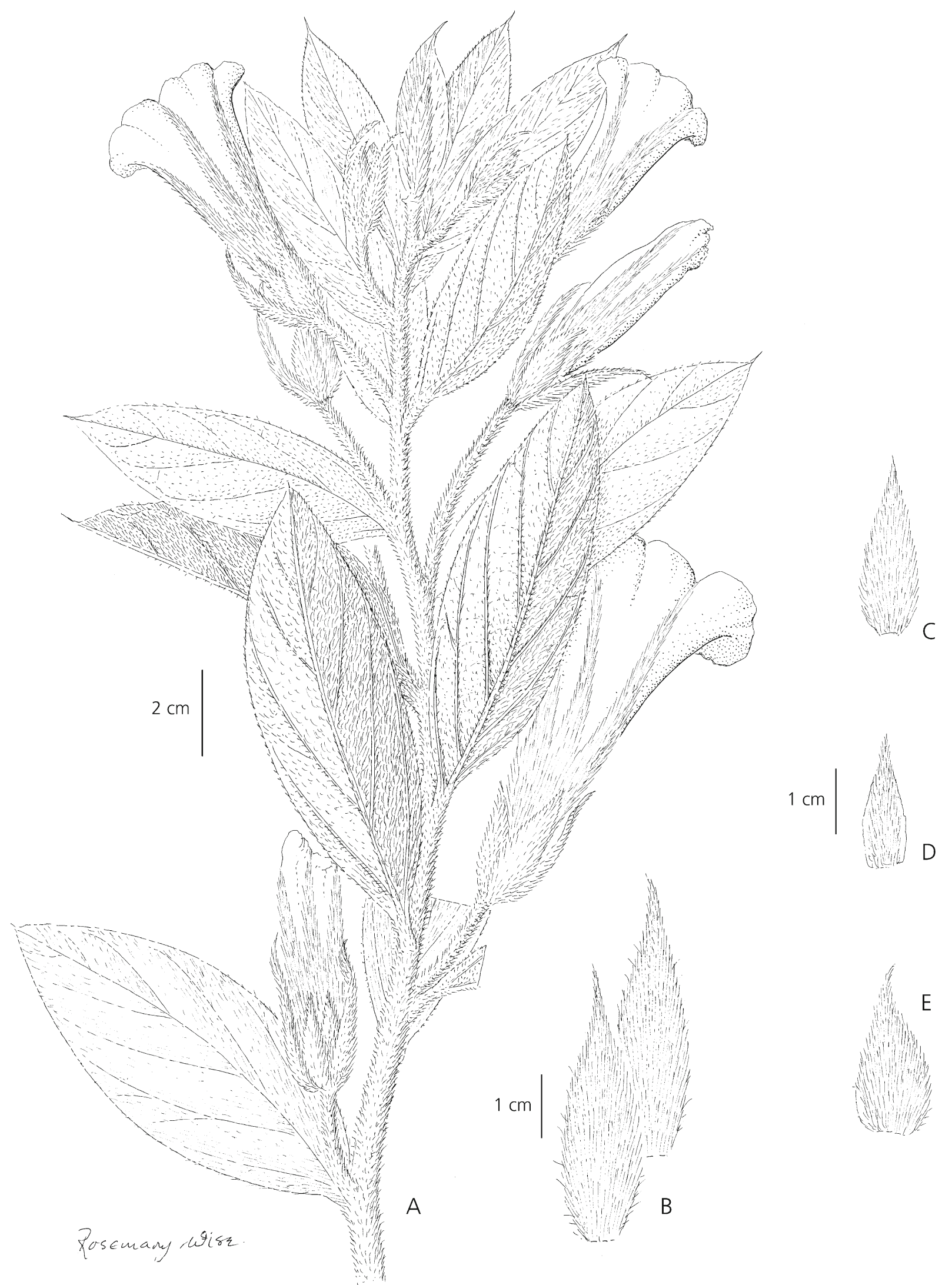

Fig. 6. Ipomoea guaranitica. A habit; B bracteoles; C outer sepal; D middle sepal; E inner sepal. From Balansa 1075. DRAWN BY ROSEMARY WISE. 
similar but with broad scarious margins; corolla $6-6.5 \mathrm{~cm}$ long, funnel-shaped, pink, pubescent, limb c. $5 \mathrm{~cm}$ diam. Capsule $1.2 \times 0.8 \mathrm{~cm}$, ovoid, glabrous; seeds $7 \times 4 \mathrm{~mm}$, blackish, glabrous. Fig. 7.

RECOGNITION. Ipomoea cordillerae is most likely to be confused with I. paraguariensis Peter and I. estrellensis Hassl. ex O'Donell because of its simple sessile leaves and somewhat silvery hairs, especially when young. It is readily distinguished from these by the ovate, acute and mucronate to finely acuminate sepals. I. paraguariensis differs in the much shorter $(6-8 \mathrm{~mm}$ at anthesis), obtuse and mucronate sepals and more strictly terminal inflorescence. I. estrellensis has a similar axillary inflorescence but differs in the broadly ovate, subacute sepals, the very short peduncles $(<4 \mathrm{~mm})$, short pedicels and the highlighted ciliolate leaf margins.

TYPIFICATION. Although there are three sheets of Balansa 4391 at Geneva, G00174792 is the only possible choice as a lectotype of Ipomoea malvaeoides var. ovata Hallier f., since it is the only sheet with an annotation by Hallier (naming the specimen "Affinis Ipomoea virgata Meisn.?", as suggested at the end of the protologue) and the only sheet conforming to the description of the inflorescence in the protologue as "pedunculi ... pluriflori". This is unfortunate as all the other original syntypes of Balansa 4391 (G00175910, G157889, P03547956, P03547967) and all other collections of $I$. cordillerae that we have seen, except Hassler 285, have solitary, long-pedunculate axillary flowers. Although we regard the two inflorescence forms as mere variations it is regrettable that the lectotype has to be associated with the less common form.

HABITAT \& DISTRIBUTION. Endemic to the low cordilleras in eastern Paraguay, where it grows in forest clearings (fide Balansa) or "campo" (fide Hassler) in the Piribebuy-Paraguarí region.

SPECIMENS EXAMINED. PARAgUAY. "Dept. Guiará: Cordillera de Villarrica, Jan. 1905”, E. Hassler 8714 p.p. (GH) - see note below. Dept. Cordillera: Cordillera de Piribebuy, April 1883, Balansa 4391 (G, P); ibid., Feb. 1885 - 1895, E. Hassler 1903 (K, P). Dept. Paraguari: Cerro Hú, 1885 - 1895, E. Hassler 285 (BM, K, P).

CONSERVATION STATUS. No modern collections have been seen in CTES, FCQ, PY, SCP or any other herbarium and as this plant has not been collected for over 110 years it may well be extinct (EX). However, the cordilleras around Piribebuy and Paraguari are difficult to explore and it may well survive and be found after careful search. The hill forest vegetation is still largely intact.

NOTE. Specimens of Hassler 8714 at BM and K and possibly elsewhere are Ipomoea paraguariensis. The specimen in the Gray herbarium (GH) cited above under I. cordillerae bears the same label as the BM and $\mathrm{K}$ specimens but represents $I$. cordillerae. There has obviously been some mislabelling here as it seems unlikely that $I$. cordillerae would occur near Villarrica, from where several collections of I. paraguariensis have been seen. The specimen at GH was presumably collected near Piribebuy.

Hassler 6760 from Valenzuela has been distributed widely under the name Ipomoea malvaeoides var. ovata following Chodat \& Hassler (1905: 690), but it represents another different species with shorter obtuse sepals, resembling but not conspecific with I. cerradoensis J. R. I.Wood \& Scotland.

\section{Ipomoea fiebrigii Hassl. ex O’Donell}

Ipomoea fiebrigii is a little known and rarely collected species described by O'Donell (1948: 169) based on a name proposed by Hassler (1917: 18). As far as we know it has only ever been found in Alto Paraná Department in Paraguay and has only been collected on three occasions, the type collection from Nucañy (Fiebrig 5675 [holotype LIL, isotypes SI, US]), a second collection by Fiebrig (Fiebrig 6706 from Ytaquiry, also at LIL) and a more recent collection, Itaipú Binacional 1081 (MO) from Reserva Tatí Yupí. Map 2. Fig. 8.

Plants from the planalto of Brazil, however, have commonly been identified as Ipomoea fiebrigii but on careful examination are clearly distinct. This Brazilian species is described as new below:

Ipomoea angustissima $J$. R. I. Wood E Scotland, sp. nov. Type: Brazil, Goiás, $16 \mathrm{~km}$ N of Alto Paraiso, Gates $\mathcal{E}^{\circ}$ Estabrook 106 (holotype RB223038!; isotype FTG!).

http:/ /www.ipni.org/urn:lsid:ipni.org:names:60473763-2

Perennial herb to $40 \mathrm{~cm}$ from a tuberous rootstock, apparently unbranched or branched near the base only; stems erect, asperous-pubescent. Leaves sessile or very shortly petiolate, compound, $1-7$ leaflets radiating out from the base, segments $0.8-5 \times$ c. $0.1-$ $0.5 \mathrm{~cm}$ linear, acute, 1 -veined, thinly pilose to \pm glabrous; petioles $0-2 \mathrm{~mm}$, thinly pilose. Inflorescence terminal consisting of single flowers or compact few-flowered cymes from the uppermost leaf axils; peduncles $1-9$ $\mathrm{mm}$, pubescent; bracteoles $3 \times 1.5-2 \mathrm{~mm}$, oblong, rounded to retuse, thinly pubescent, margin scarious, caducous; pedicels $3-7 \mathrm{~mm}$, pubescent; sepals subequal, $5-8 \times 5-6 \mathrm{~mm}$, elliptic, obtuse to rounded, pubescent except for the scarious margins, outer sometimes mucronulate, reddish, margins narrow, inner more rounded with broader scarious margins; corolla $3.5-4 \mathrm{~cm}$ long, funnel-shaped, pink, pubescent, limb c. $2.5 \mathrm{~cm}$ diam., somewhat lobed; stamens included; filaments glabrous except for pubescent bases, unequal, shorter $6-7 \mathrm{~mm}$, longer $9-10 \mathrm{~mm}$, anthers $2.5-3 \mathrm{~mm}$ long; ovary glabrous, style $10-11 \mathrm{~mm}$ long, glabrous. Capsule and seeds not seen. Fig. 9. 


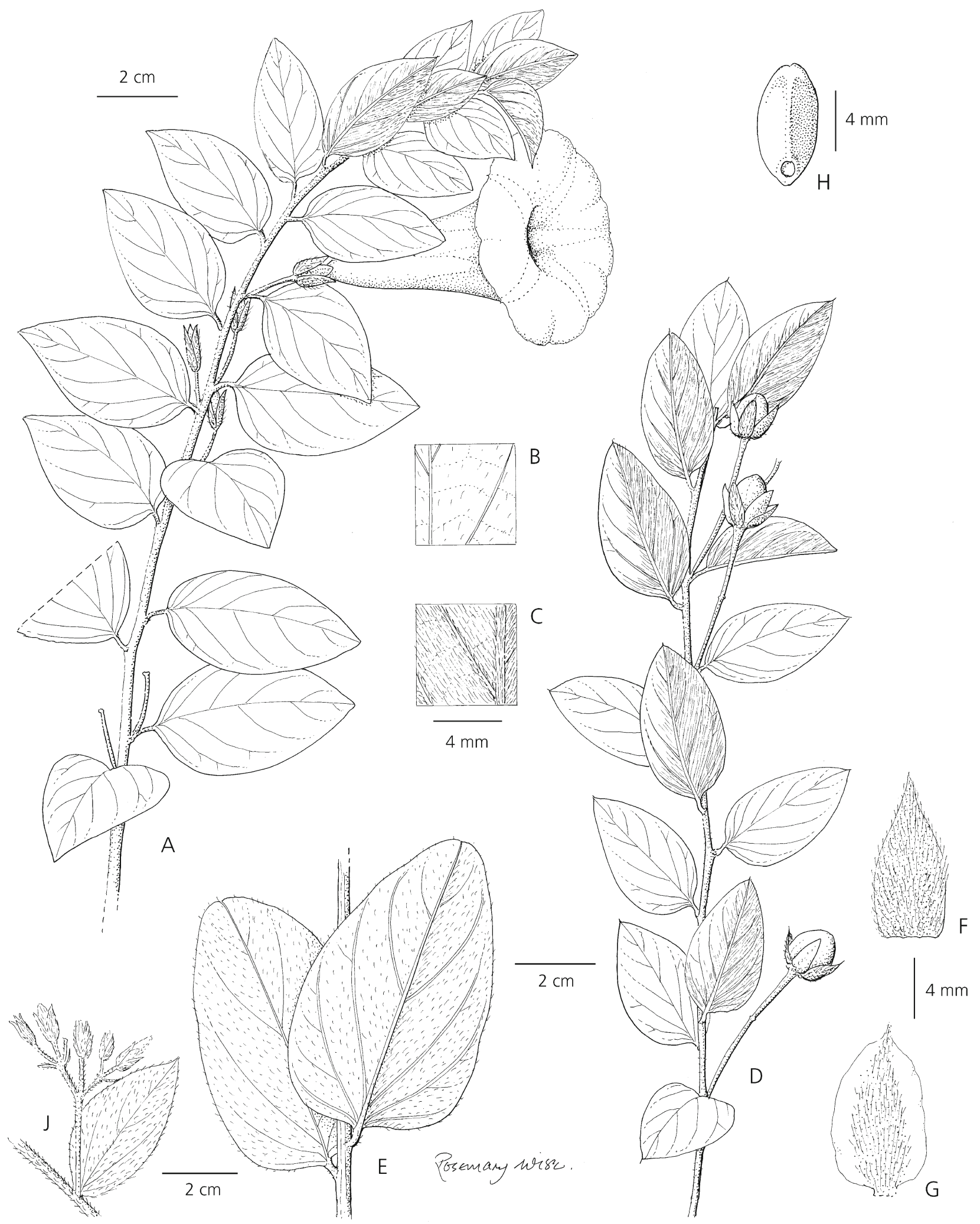

Fig. 7. Ipomoea cordillerae. A habit (flowering plant); B adaxial leaf surface; C abaxial leaf surface; D habit (fruiting plant); E portion of stem and leaves; F outer sepal; G inner sepal; H seed; J form with branched inflorescence. A - C from Hassler 8714 (GH); D - H from Balansa 4391: J from Hassler 485. DRAWN BY ROSEMARY WISE. 


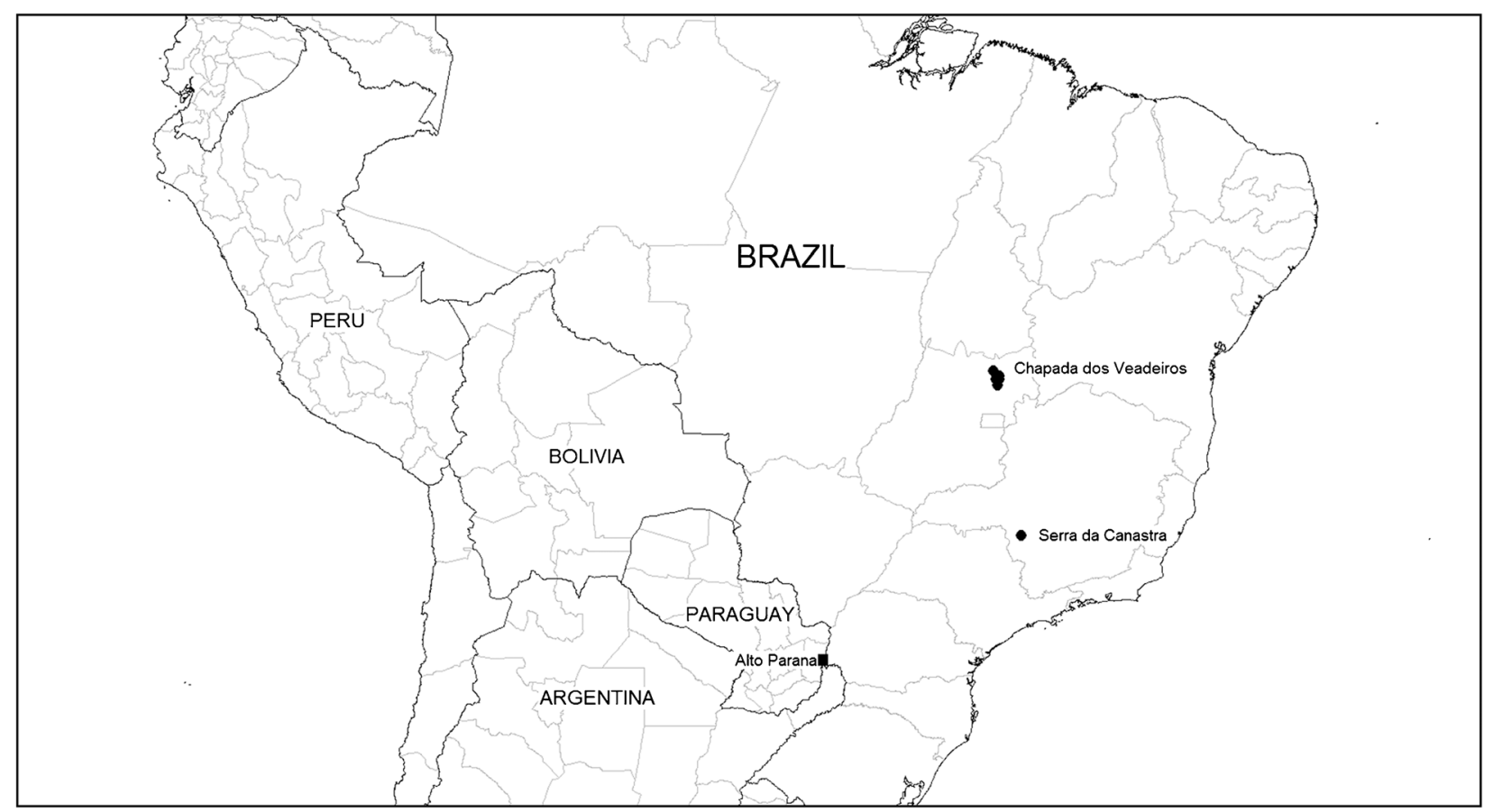

Map 2. Map of Brazil and neighbouring countries showing distribution of Ipomoea fiebrigii ( $\bullet$ ) in Río Paraná basin in Paraguay and I. angustissima $(\bullet)$ in two isolated upland areas of Central Brazil.

RECOGNITION. Ipomoea angustissima differs from I. fiebrigii in the short, appressed, somewhat stiff hairs of the stem, leaves, sepals and corolla exterior. In I. fiebrigii the indumentum is of relatively long, soft, whitish hairs these being particularly prominent on the exterior of the corolla and the sepals (Fig. 8). Additionally the sepals of I. angustissima are \pm rounded, $5-8 \mathrm{~mm}$ in length, whereas those of I. fiebrigii are $9-$ $11 \mathrm{~mm}$ long, the outer narrowed to a truncate, mucronulate apex, the inner tapered to a subacute apex. In I. angustissima the inflorescence is often (but not always) subterminal and the inflorescence is formed of 1 - 3-flowered cymes (Fig. 9A). In contrast I. fiebrigii has solitary axillary flowers (Fig. 8A). The upper part of the stem and peduncles of I. angustissima may be sticky as granules of sand stick to the hairs, the stem appearing superficially to be granulose.

HABITAT \& DISTRIBUTION. Campo húmedo at relatively high altitudes of between 1000 and 1600 m. Apparently restricted to the Chapada de Veadeiros in Goiás with an outlying population in the Serra de Canastra in Minas Gerais. Map 2.

SPECIMENS EXAMINED. BRAZIL. Goiás: Chapada dos Veadeiros, c. $20 \mathrm{~km} \mathrm{~W}$ of Alto Paraiso (formerly Veadeiros), $1000 \mathrm{~m}, 10 \mathrm{Feb}$. 1966, H. S. Irwin et al. 12542 (MO, NY); c. $65 \mathrm{~km}$ due N of Brasilia, $1700 \mathrm{~m}$, 21 Dec. 1968, R. M. Harley et al. 11361 (K); ibid., M. J. Graziela E् A. Lima 829-68 (IPA, OXF); ibid., M. J. Chavez 280 (JPB); $5 \mathrm{~km} \mathrm{~N}$ of Alto de Paraiso, $1250 \mathrm{~m}$, 22 March 1971, H. S. Irwin et al. 32976 (MO, NY); $16 \mathrm{~km}$ N of Alto Paraiso, 1600 m, 3 Feb. 1979, Gates $\mathcal{E}^{\circ}$
Estabrook 106 (FTG, RB); ibid., 22 - 25 km N de Alto Paraiso, c. 1500 m, 4 Feb. 1990, M. M. Arbo et al. 3589 (CTES, HRCB); Estrada de Alto Paraiso para São Jorge, 1 Feb. 2004, J. F. B. Pastore et al. 773 (CEN); Mun Cavalcante, Caminho de Kalunga, frente entrada a Faz. Vicente, 3 Feb. 2004, J. F. B. Pastore et al. 816 (CEN); sin. loc. Glaziou 21792 (K). Minas Gerais: P.N. Serra da Canastra, São Roque de Minas, R. Romero et al. 4796 (SP).

CONSERVATION STATUS. This species is restricted to two chapadas in central Brazil, both enjoying legal protection. We have no knowledge of its frequency in either location but it seems to be tolerably frequent in the Chapada de Veadeiros. Without further studies, this species must be classified as Data Deficient within IUCN (2012) guidelines.

EPONYMY. The epithet angustissima, meaning very narrow, refers to the very narrow leaf segments.

\section{Species confused with Ipomoea hirsutissima Gardner}

Ipomoea hirsutissima was described by Gardner based on his own collection from Goías. As with the cases of I. decora and I. elegans cited earlier, Meisner (1869) seems not to have seen species published by earlier botanists and went on to newly describe the same species under different names, thus both I. hirsutissima and I. chrysotricha Meisn. appear in Flora Brasiliensis. We agree with Austin et al. (2015) that these two represent the same species and that 

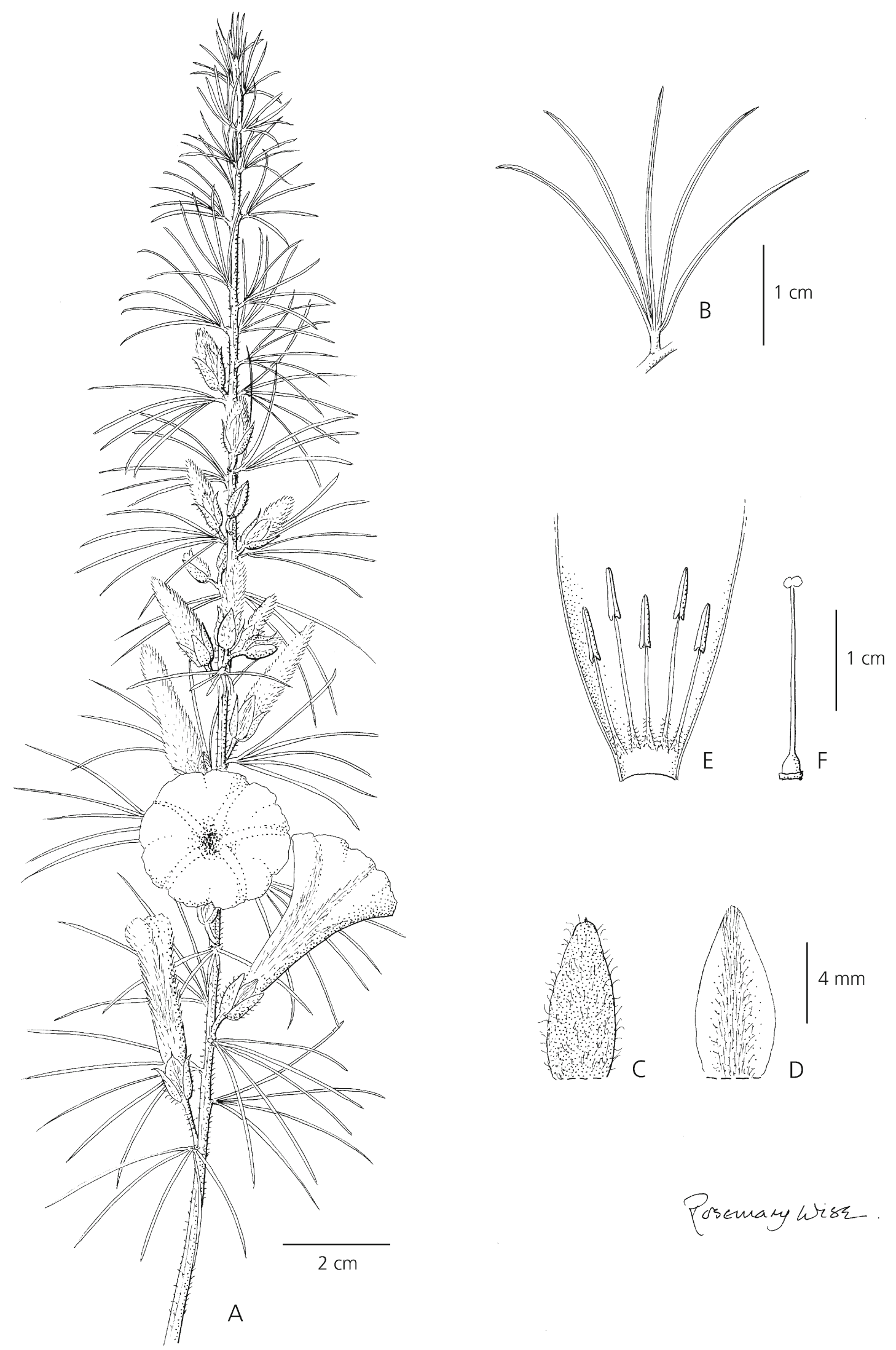

Fig. 8. Ipomoea fiebrigii. A habit; B leaf; C outer sepal; D inner sepal; E corolla opened out; F ovary and style. From Itaipu Binacional 1081. DRAWN BY ROSEMARY WISE. 


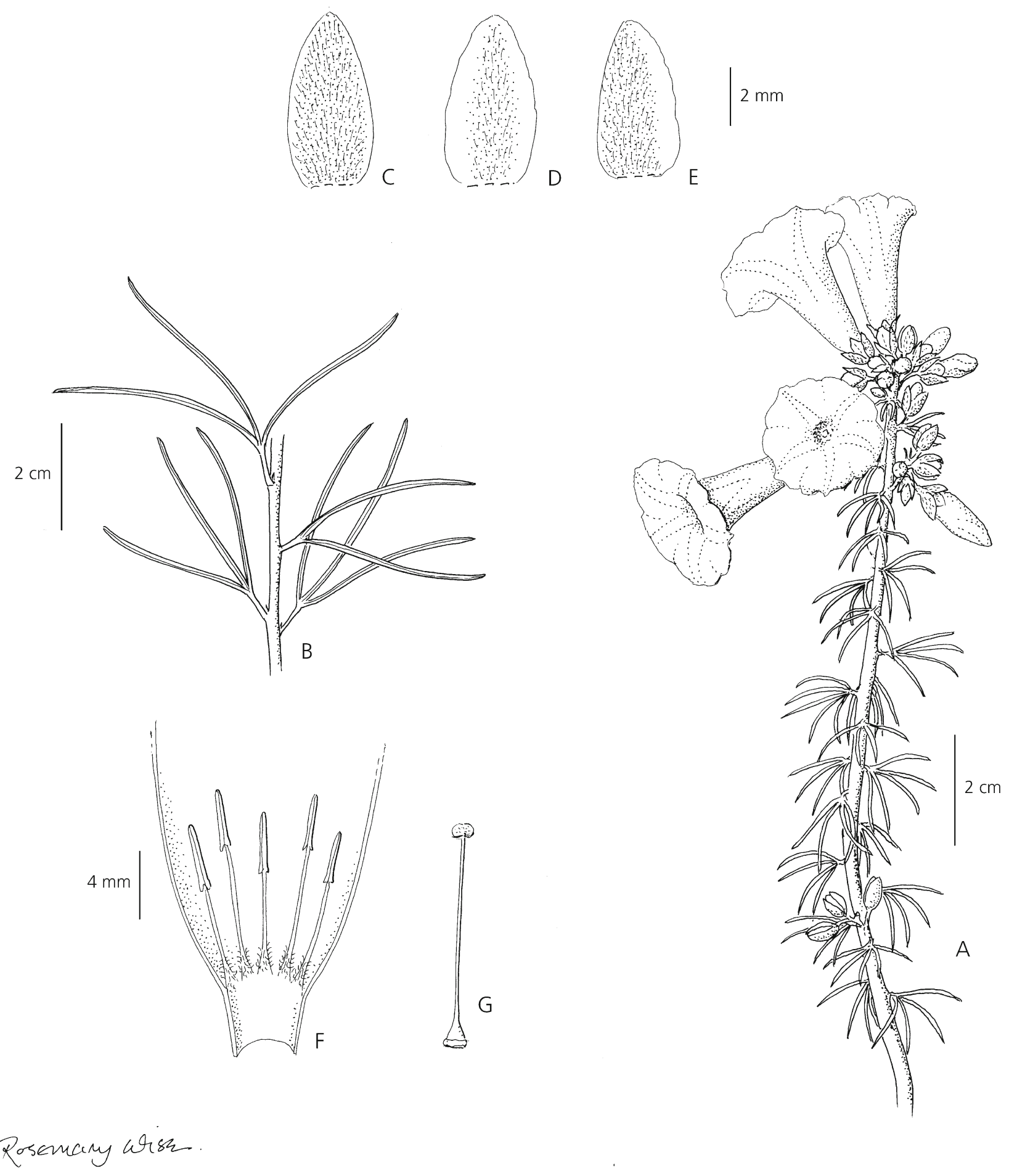

Fig. 9. Ipomoea angustissima. A habit; B stem showing leaves; C outer sepal; D middle sepal; E inner sepal; F corolla opened out; G ovary and style. A from Harley et al. 11361; B from Gates \& Esterbrook 106; C - G from Irwin et al. 12542. DRAWN BY ROSEMARY WISE.

I. chrysotricha and its varieties should be treated as synonyms of I. hirsutissima. There is a good isotype of I. chrysotricha (Riedel 610) at NY but, as we doubt Meisner saw the isotype of I. chrysotricha (Riedel 610) at NY and, as the top set of Riedel's collections is in St Petersburg (LE), we have chosen the St Petersburg specimen as lectotype. We have included the other recognised varieties of I. hirsutissima in the synonymy and have also lectotypified var. integrifolia Chodat \& Hassl., choosing the best of 
the three specimens at Geneva. The full synonymy is set out below:

Ipomoea hirsutissima Gardner (1842: t. 471). Type: Brazil, Goías, Mision of Duro, Oct. 1839, Gardner 3355 (lectotype K000612806!, designated here, isolectotypes GH!, K!, P!).

Ipomoea chrysotricha Meisn. (Meisner 1869: 243). Type: Brazil, Sao Paulo, Rio Pardo Riedel 610 (lectotype LE!, designated here, isolectotype NY00319173!).

Ipomoea chrysotricha Meisn. var. ovata Meisn. (Meisner 1869: 243). Type: Brazil, [Minas Gerais], Serra de Christaes, Pohl s.n. (BR0000530689, possible isotype). Ipomoea chrysotricha Meisn. var. boliviana Meisn. (Meisner 1869: 243). Type: Bolivia, Santiago de Chiquitos, A. D'Orbigny 928 (P03878901!, lectotype, designated by Wood et al. 2015: 38, isolectotype BR0000530753).

Ipomoea hirsutissima var. integrifolia Chodat \& Hassl. (Chodat \& Hassler 1905: 688). Type: Paraguay, Ipe Hú, Sierra de Maracayú, E. Hassler 5007 (lectotype G00174906, designated here, isolectotypes G00174907, G00174905, K, P, UC).

Ipomoea hirsutissima var. repens Glaz. (Glaziou 1910: 481).

Type: Brazil, Goyaz, Chico Lobo, Glaziou 21791 (holotype P, isotypes BR000005307241, G00227885).

Ipomoea hirsutissima is an erect species with a characteristic indumentum of long spreading rough hairs covering all vegetative parts as well as the exterior of the corolla. The hairs have bulbous bases which are often blackish as in the image in Wood et al. (2015: 40). The very acute to acuminate sepals about 12 $16 \mathrm{~mm}$ in length are also distinctive. I. hirsutissima is widely distributed in several localities in Bolivia, Brazil and Paraguay but is rarely collected and appears to be uncommon in all three countries. In Brazil most records are from Minas Gerais and it appears to be very rare elsewhere with only a handful of records from Goías, Mato Grosso, Mato Grosso do Sul (Dubs 1998: 76) and São Paulo.

Among Brazilian plants Ipomoea hirsutissima is only likely to be confused with $I$. aurifolia Dammer, which is similar in indumentum and facies but differs in having narrower, usually lanceolate leaves, rather than the oblong-elliptic to obovate leaves of I. hirsutissima. Additionally I. aurifolia has much shorter obtuse to subacute sepals. It appears to be restricted to the Distrito Federal around Brasilia and neighbouring parts of Goías. Inexplicably it was treated as a synonym of I. campestris Meisn. by Austin et al. (2015) but differs in its distinctive indumentum and shorter subacute sepals as set out in the key below.

Austin et al. (2015), did, however treat another species, Ipomoea pyrenea Taub. as a synonym of I. hirsutissima. We believe this was mistaken. I. pyrenea is a little-known species endemic to the Serra de Pireneus in Goías (Map 3). It has distinctive oblong leaves $2.5-5 \times 0.3-$ $0.7 \mathrm{~cm}$ and a subterminal inflorescence. The cymes are subsessile even below and the sepals are only $8-11 \mathrm{~mm}$ in length. The leaves and stems are softly and thinly pubescent with appressed hairs, an indumentum quite different from that of I. hirsutissima. As this species is rare and localised we have provided an illustration (Fig. 10) and cited all the specimens we have seen below:

Ipomoea pyrenea Taub. (Taubert 1895: 449). Type: Brazil, Goiás, Serra dos Pyreneus, Ule 3011 (holotype $\mathrm{B} \dagger$, isotypes HBG506564!, P03551472!, R000040279!).

SPECIMENS EXAMINED. BRAZIL. Goiás: Serra dos Pirineus, Corumbá de Goías, 1555'25"S 4848'30"W, 18 Dec. 1951, A. Macedo 3501 (NY, S); Serra dos Pireneus, c. $21 \mathrm{~km} \mathrm{E}$ of Pirenópolis, $1000 \mathrm{~m}, 16$ Jan. 1972, H. S. Irwin et al. 34376 (FTG, NY); ibid., Mun. Pirenópolis, Faz. Solar dos Pireneus, 1300 m, 12 Feb. 2000, G. Hatschbach et al. 70081 (MBM); Cocalhizino de Goías, Areias, 1549'24"S 4841'54"W, 1262 m, 23 Nov. 2011, D. P. Saraiva et al. 275 (RB, SP).

A further species, from Paraguay, was originally identified as Ipomoea hirsutissima by Hassler and agrees with it in habit, indumentum, shortly petiolate leaves, persistent linear-lanceolate bracteoles, sepal shape and the usually solitary flowers. It differs however in the presence of some trifurcate leaves and the much larger corolla which is usually about $9 \mathrm{~cm}$ in length whereas in I. hirsutissima it is only $6-7 \mathrm{~cm}$ long. O'Donell apparently regarded it as belonging to I. acutisepala O'Donell and in 1953 identified the isotype in SI as a "forma" of this species. However he did not cite Hassler 9114 when describing I. acutisepala (O'Donell 1950b) or in his account of Ipomoea in Argentina (O'Donell 1959b), although the corolla and sepal dimensions given in the descriptions suggest that he included its dimensions when preparing the original protologue (O'Donell 1950b). It is described as new below:

Ipomoea megalantha $J$. R. I. Wood E Scotland, sp. nov. Type: Paraguay, in viciniis Caaguazú, E. Hassler 9114 (holotype BM!; isotypes G, K!, MO!, NY!, S!, SI!, US!).

http://www.ipni.org/urn:lsid:ipni.org:names:60473764-2

Perennial subshrub; root a woody xylopodium of unknown size but at least $2 \mathrm{~cm}$ thick and $8 \mathrm{~cm}$ long; stems decumbent or ascending, woody, pilose, glabrescent when old, $10-40 \mathrm{~cm}$ long. Leaves shortly petiolate, $1.5-9.5 \times 0.5-5 \mathrm{~cm}$, oblong to ovate, obovate or elliptic, often trifurcate on the same plant, apex obtuse or acute, mucronate, base broadly to 


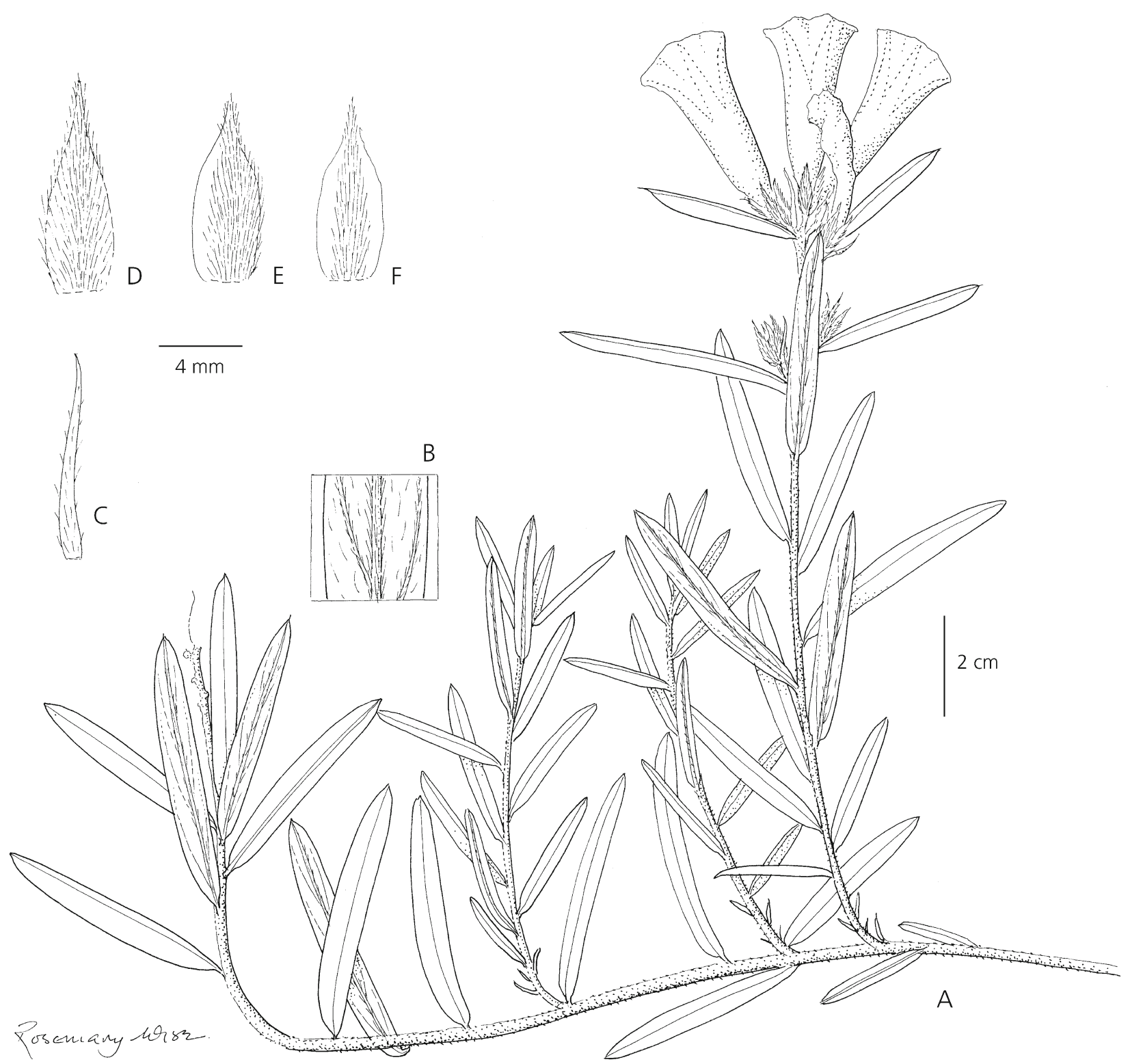

Fig. 10. Ipomoea pyrenea A habit; B abaxial leaf surface; C bracteole; D outer sepal; E middle sepal: $\mathrm{F}$ inner sepal. From Irwin et al. 34376. DRAWN BY ROSEMARY WISE.

narrowly cuneate, margin entire, both surfaces pilose, more densely so on the veins; petioles $2-9 \mathrm{~mm}$, pilose. Inflorescence of solitary, axillary flowers arising from towards the base of the stem; peduncles $2.5-6$ $\mathrm{cm}$, pilose; bracteoles $13-27 \times 1-3 \mathrm{~mm}$, linearlanceolate, pilose, persistent; pedicels $3-11 \mathrm{~mm}$, pilose; sepals slightly unequal, lanceolate, finely acuminate, outer $17-20 \times 3-6 \mathrm{~mm}$, abaxially pilose, inner up to $22 \mathrm{~mm}$ long, the central area pilose, the margins scarious, glabrous; corolla 8.5 - $9.5 \mathrm{~cm}$ long, \pm funnel-shaped, gradually widened from base, midpetaline bands densely pilose; limb $5-6 \mathrm{~cm}$ diam., unlobed; stamens included, anthers glabrous except widened, hirsute basal part, longer c. $22 \mathrm{~mm}$; shorter 13 - $15 \mathrm{~mm}$; style 20 - $21 \mathrm{~mm}$ long, glabrous, stigma bilobed, subglobose; ovary glabrous. Capsule and seeds unknown. Fig. 11.

RECOGNITION. Ipomoea megalantha is distinct from all related species by its much larger corolla which is about $9 \mathrm{~cm}$ in length. It is similar in habit and indumentum to I. hirsutissima but is also distinguished by the presence of trifurcate leaves. I. acutisepala differs in its longer trailing stems, leaves with petioles $1-3 \mathrm{~cm}$ long, the shorter, somewhat caducous bracteoles, the usually branched inflorescence, shorter sepals (13 - $17 \mathrm{~mm}$ long) and shorter corolla.

HABITAT \& DISTRIBUTION. Only known from the Department of Caaguazú in Paraguay, where it grows in "campos" (fide Balansa and Jorgensen) or in cerrado 


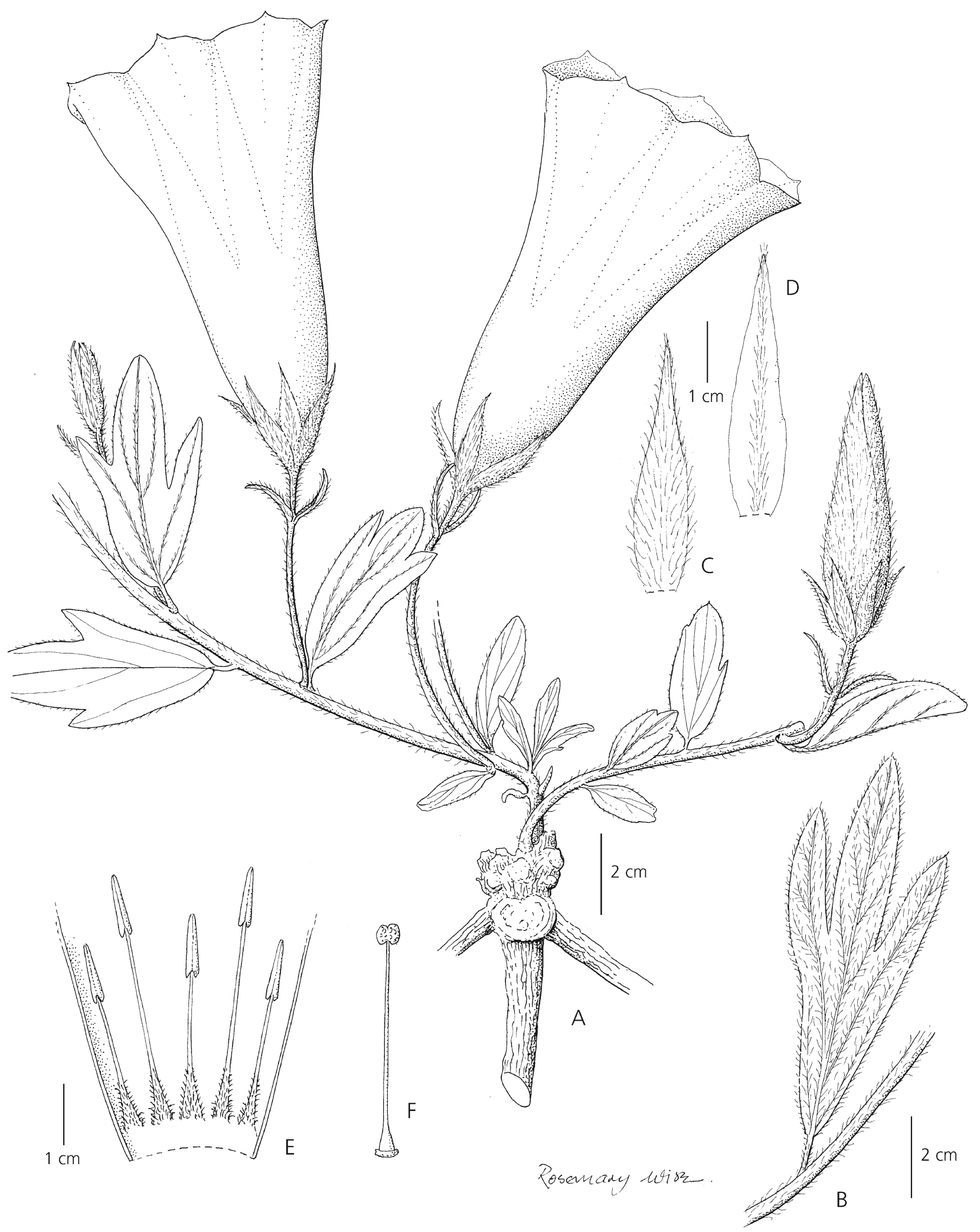

Fig. 11. Ipomoea megalantha. A habit; B leaf; C outer sepal; D inner sepal; E corolla opened out; F ovary and style. A, C - F from Hassler 9114; B from Jorgensen 4859. DRAWN BY ROSEMARY WISE. 


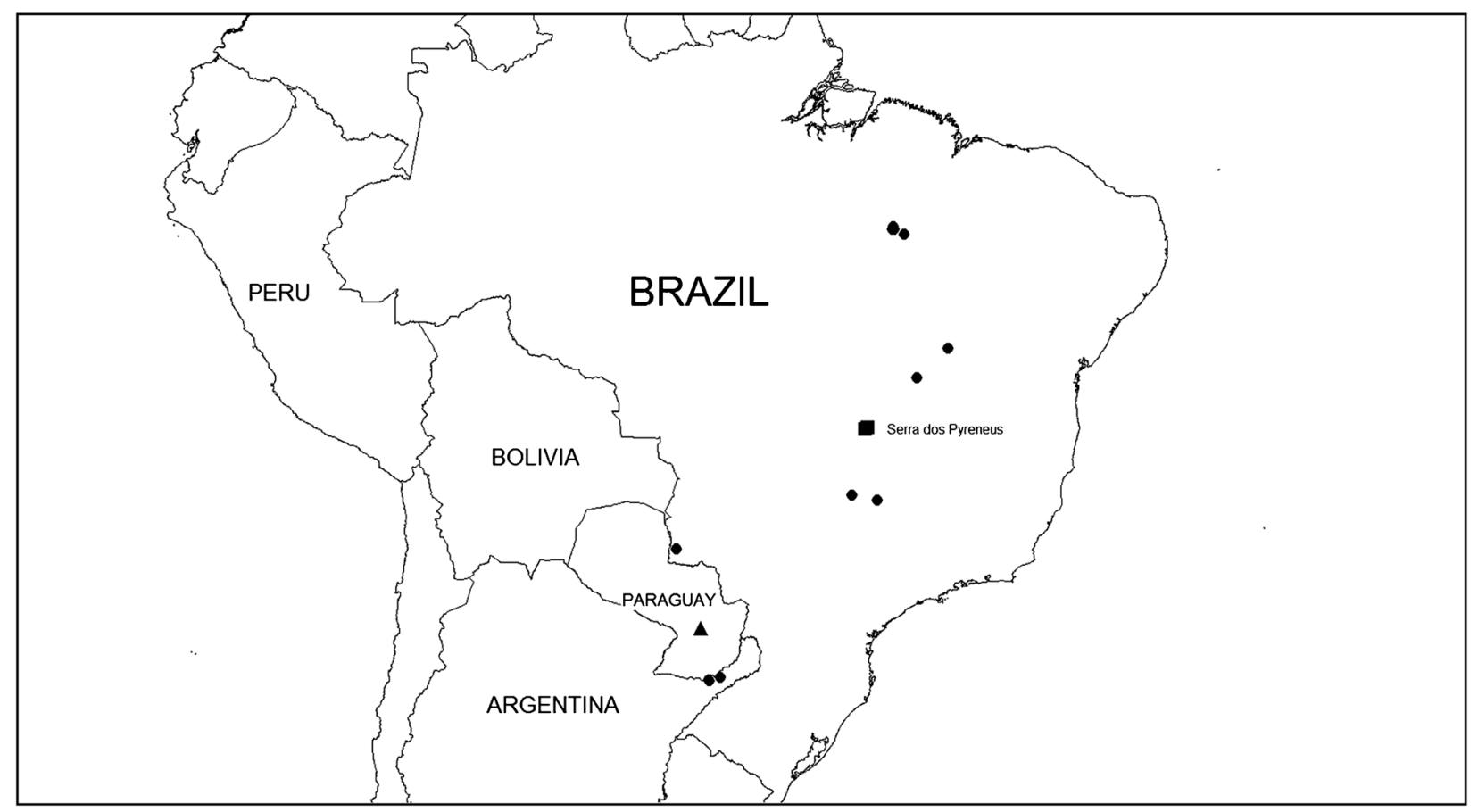

Map 3. Map of Brazil and neighbouring countries showing the scattered distribution of Ipomoea aequiloba $(\bullet)$ and the distribution of the narrowly endemic species I. megalantha ( $\mathbf{\Delta})$ and I. pyrenea ( $\mathbf{\square})$

(fide Krapovickas) and, from the habit of the plant, it appears to be a cerrado species. Map 3.

SPECIMENS EXAMINED. PARAguAY. Dept. Caaguazú: 11 Nov. 1874, B. Balansa 1174 (P); ibid., March 1905, E. Hassler 9114 (holotype BM; isotypes G, K, NY, SI, US); "Thú", Feb. 1932, P. Jorgensen 4859 (A, F, S); $32 \mathrm{~km}$ N of Caaguazú, camino a Yhú, 19 Oct. 1994, A. Krapovickas et al. 45769 (K).

CONSERVATION STATUS. Ipomoea megalantha has been collected four times over 140 years so it is clearly very rare. We have no idea of the extent of original populations but it must be at risk from habitat destruction and the presence of invasive grass species of African origin. If, as is likely, this is a cerrado species, search should be made in the spring after fire has passed through any grasslands which survive. This species should be provisionally classified as Critically Endangered (CR) based on its very restricted, although undefined range, and the known vulnerability of its habitat. Field work is urgently needed to confirm its status and, as seems necessary, steps should be taken to secure the conservation of one of the most spectacularflowered species of Ipomoea.

NOTES. In Paraguay Ipomoea megalantha is restricted to Caaguazú whereas I. hirsutissima appears to be restricted to the Sierra de Maracayú in Canindeyú Department (Hassler 5007) and Alto Paraná (G. Caballero 1184 at G). I. acutisepala was described from Argentina (Misiones) and extends into Santa Catarina and Paraná in Brazil but apparently not into Paraguay.

\section{Key to species commonly confused with Ipomoea hirsutissima}

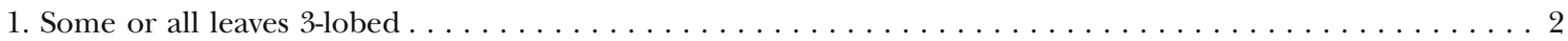

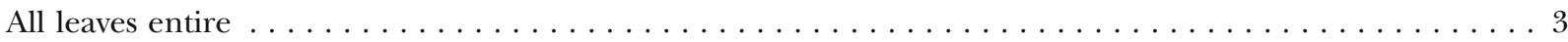

2. Corolla $>8 \mathrm{~cm}$ long; stems ascending or erect, $10-40 \mathrm{~cm}$ long; flowers solitary, very rarely paired ........I. megalantha Corolla $<7 \mathrm{~cm}$ long; stems decumbent, trailing, rarely less than $50 \mathrm{~cm}$ long; flowers 1 - many but very rarely solitary.

I. acutisepala

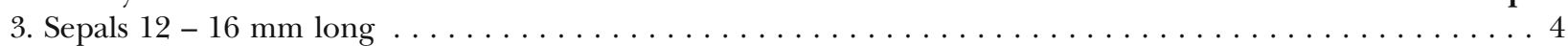

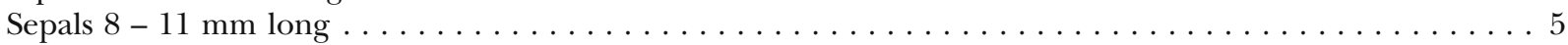


4. Indumentum of stem, leaves, sepals and corolla of long, spreading hispid hairs; sepals terminating in a long fine point.

I. hirsutissima

Indumentum of stem, leaves, sepals and corolla of appressed hairs; sepals subacute to acute

.I. campestris

5. Sepals obtuse to subacute; leaves usually lanceolate, roughly hirsute, $>1 \mathrm{~cm}$ wide; cymes distinctly pedunculate except at apex of stem $\ldots \ldots \ldots \ldots \ldots \ldots \ldots \ldots \ldots \ldots \ldots \ldots \ldots \ldots \ldots \ldots$ aurifolia Sepals acute; leaves appressed pubescent, $<1 \mathrm{~cm}$ wide, cymes all sessile or nearly so . . . . . . . . . . pyrenea

The identity of Ipomoea carajasensis D. F. Austin and its consequences

Ipomoea carajasensis was described by Dan Austin from the Serra dos Carajás in Para State, Brazil, in a paper on Amazonian Convolvulaceae (Austin 1981). The plant was not illustrated and neither the holotype nor the paratype were returned to the cited herbarium (MG). Over the years the name I. carajasensis has been applied to plants similar to I. maurandiodes Meisn. from the cerrados of Goiás and Minas Gerais.

In April 2015 John Wood was able to visit the Tucson herbarium (ARIZ) where he examined material sent to Dan Austin for determination as well as material transferred on permanent loan to Arizona from Fairchild (FTG). Amongst this material was the holotype of Ipomoea carajasensis loaned by MG and probably now returned.

Examination of this material shows that Ipomoea carajasensis is conspecific with I. maurandiodes and as far as we know, all material of "I. carajasensis" collected from this mountain, for example Sperling et al. 5610 (K, NY) and R. S. Secco et al. 132 (MG, MO, SP)], should be named $I$. maurandioides.

Ipomoea maurandiodes is a widespread species often growing on rock outcrops or in sandy cerrado extending from NE Argentina (O'Donell 1959b), eastern Paraguay and eastern Bolivia (Wood et al. 2015) through the cerrados of Brazil north to Pará State. The synonymy is given below.

Ipomoea maurandioides Meisn. (Meisner 1869: 275). Type: Brazil, Rio Grande do Sul, Porto Alegre, Sello 3619 (holotype $\mathrm{B} \uparrow$, image $\mathrm{F}$ !).

Ipomoea carajasensis D. F. Austin (1981: 291), synon. nov. Type: Brazil, Pará, Marabá, Serra dos Carajas, 700 m, P. Cavalcante 2115 (holotype MG!).

Ipomoea serpens auct. mult., incl. Austin et al. 2015: 630.

Ipomoea maurandiodes is a quite variable species in leaf shape, indumentum and inflorescence. Leaves vary from lanceolate to ovate with rounded to acute auricles. Plants are usually glabrous but hirsute forms occur sporadically throughout most of its range and can be recognised as var. subtomentosa (O'Donell) J. R. I. Wood \& Scotland. The inflorescence is commonly formed of solitary axillary flowers but is cymose in quite a few collections. However, the slender habit and very unequal, often prominently veined sepals with the inner sepals ovate, rounded to obtuse and mucronate make this species relatively distinct. Fig. 12.

Although O'Donell (1952: 242) pointed out that Ipomoea serpens Meisn. was not conspecific with I. maurandiodes and stated it to be "indudablemente" conspecific with a polymorphic I. asarifolia (Desr.) Roem. \& Schult., this has often been ignored and the claim that $I$. serpens Meisn. is conspecific with I. maurandioides was repeated in Austin et al. (2015) and in the Flora do Brasil 2020 em construção website when accessed on 19 April 2016. I. serpens Meisn. is indeed related to $I$. asarifolia, rather than I. maurandioides but we believe it is distinct and have renamed it I. paludicola J. R. I. Wood \& Scotland (Wood et al. 2015).

However, not all plants named Ipomoea carajasensis belong to $I$. maurandioides. In particular, plants with lanceolate, acuminate and mucronate sepals are clearly a distinct species. These are easily recognised by the distinctive oblong, sagittate leaves in which the two auricles are also oblong and resemble the main leaf blade, the leaf thus appearing 3-lobed. This is described below.

Ipomoea aequiloba $J$. R. I. Wood E S Scotland, sp. nov. Type: Brazil, Tocantins, Mun. Tocantinopolis, km 18 estrada vecinal á Ferrovia Norte Sul, 6 $38^{\circ} 50^{\prime \prime} \mathrm{N}$ 47²9'56"W, 190 m, 21 Feb. 2005, G. Pereira-Silva et al. 9483 (holotype CEN!).

http:/ /www.ipni.org/urn:lsid:ipni.org:names:60473765-2

Slender trailing perennial; glabrous in all parts. Leaves shortly petiolate, $0.8-2.5 \times 0.1-0.4 \mathrm{~cm}$, sagittate, appearing equally trilobed, the central lobe linear to very narrowly oblong, acute, the two linear acute auricles, resembling, \pm equalling or slightly shorter than the central lobe, both surfaces glabrous; petioles $0.6-3 \mathrm{~cm}$. Inflorescence of solitary axillary pedunculate flowers; peduncles $15-20 \mathrm{~mm}$, commonly bent at a sharp angle at apex; bracteoles scale-like, c. $1 \mathrm{~mm}$ long; pedicels $6-13 \mathrm{~mm}$, often thickened upwards 


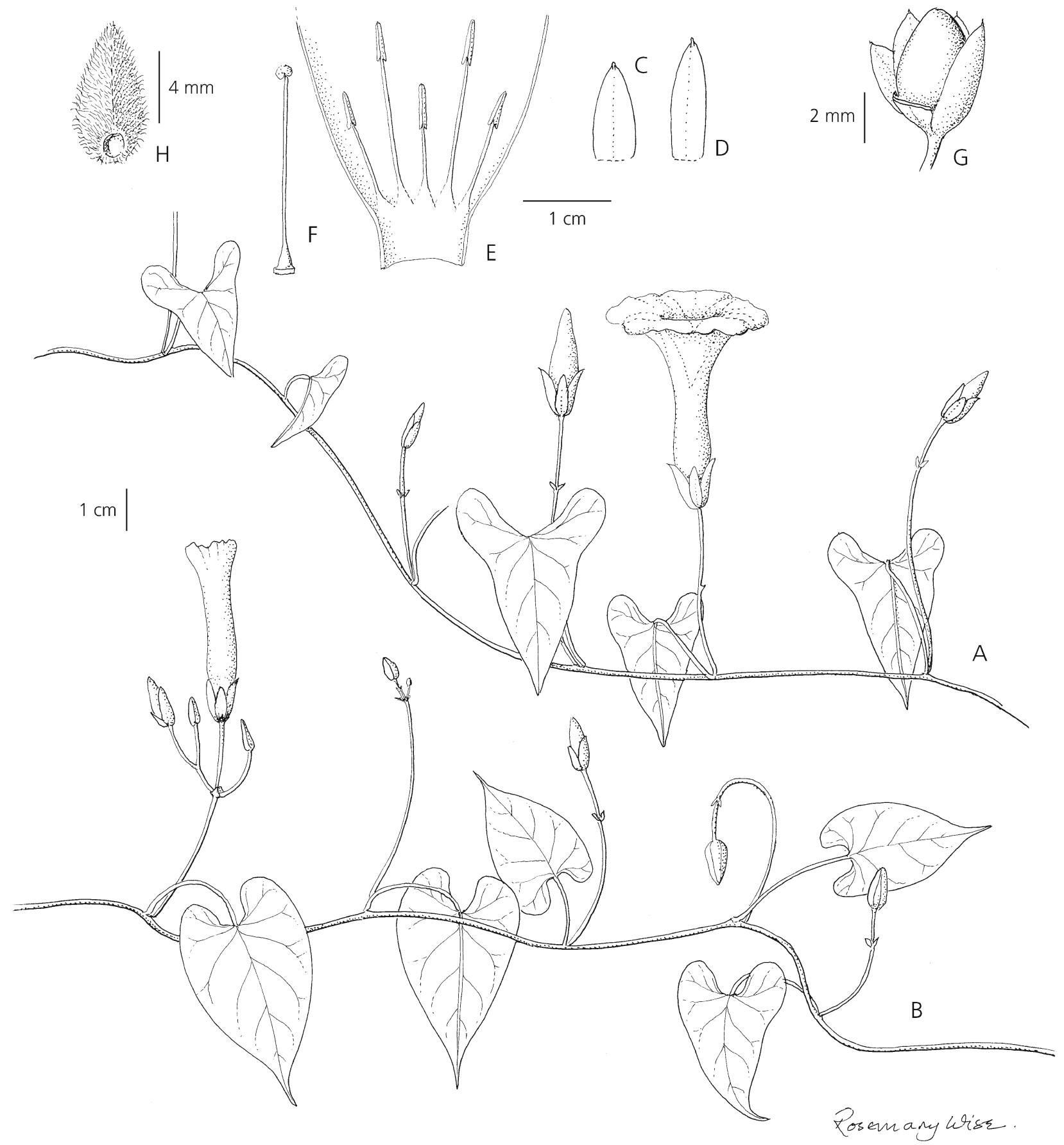

Fig. 12. Ipomoea maurandioides. A habit with solitary flowers; B habit with cymose inflorescence; C outer sepal; D inner sepal; E corolla opened out to show stamens; F ovary and style; G capsule; H seed. A from Petersen 14655; B - F from Wood \& Williams 27842; G - H from Wood \& POZO 25056. DRAWN BY ROSEMARY WISE.

and stouter than peduncle; sepals unequal, broadly lanceolate, acuminate and mucronate, glabrous, outer pair unequal $4.5-8 \times 2-3 \mathrm{~mm}$; inner $12-14 \times 3 \mathrm{~mm}$; corolla $6.5 \mathrm{~cm}$ long, funnel-shaped, pink, glabrous; limb c $4.5 \mathrm{~cm}$ diam., the midpetaline bands ending in a tiny tooth; filaments glabrous apart from hirsute bases, unequal, shorter c. $5 \mathrm{~mm}$ long, longer c. $10 \mathrm{~mm}$; ovary glabrous; style $15 \mathrm{~mm}$ long, glabrous. Capsule c. 6 $\times 5 \mathrm{~mm}$, subglobose, glabrous, muticous; seeds $4.5 \times 3$ $\mathrm{mm}$, ellipsoid, uniformly pale brown-tomentellous. Fig. 13.

RECOGNITION. Ipomoea aequiloba is clearly related to both I. maurandioides and the recently described I. mucronatoproducta J. R. I. Wood \& Scotland. All three are relatively slender, usually trailing herbs with 


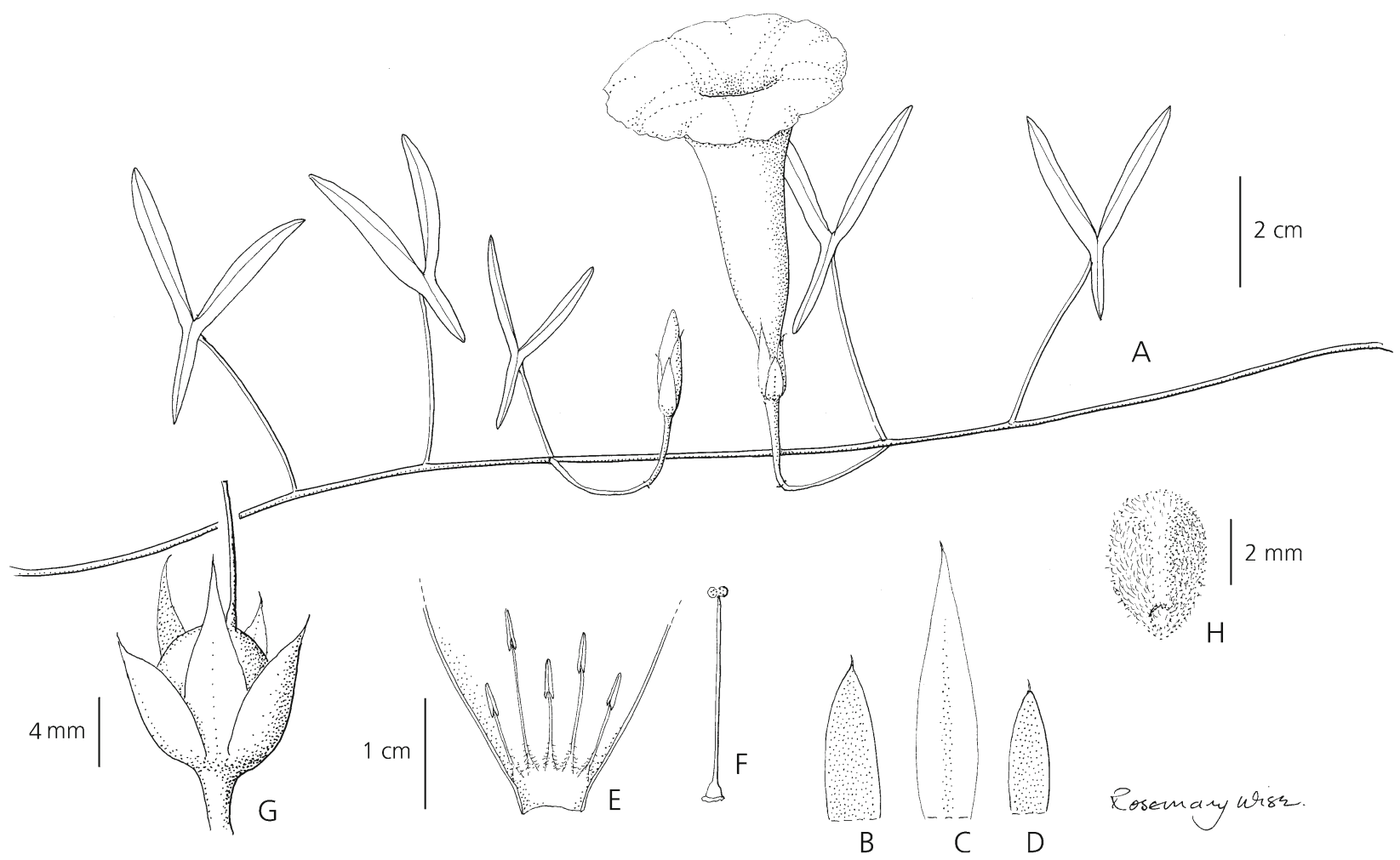

Fig. 13. Ipomoea aequiloba. A habit; B outer sepal; C middle sepal; D inner sepal; E corolla opened out; F ovary and style; G capsule; H seed. A from Macedo 86, B - H from Hatschbach 42084. DRAWN BY ROSEMARY WISE.

unequal sepals and usually solitary, medium-sized pink flowers. From I. maurandioides the new species is distinguished by having always solitary flowers and all the sepals lanceolate and finely acuminate, rather than the inner sepals oblong-oblanceolate and mucronate as illustrated in O'Donell 1959b: 188. From I. mucronatoproducta it is distinguished by the midpetaline bands terminating in a small tooth rather than in a long fine point up to $6 \mathrm{~mm}$ in length. From both it is immediately distinguished by the distinctive, apparently 3-lobed leaves in which the two auricles are more or less equal with the blade.

HABITAT \& DISTRIBUTION. A plant of the Brazilian cerrados extending into NE Argentina growing between 150 and $600 \mathrm{~m}$. It has a very wide but very scattered distribution (Map 3) but there does not seem to be any significant difference between specimens collected in Argentina and those from central Brazil.

SPECIMENS EXAMINED. ARgentinA. Misiones: Dept. Candelaria, Colonia Tacuaruzu, March 1964, R. Martínez Crovetto 9960 (CTES); ibid., Santa Ana, camino a La Cruz, 27²5'07"S 55 34'14"W, 158 m, 9 April 2016, H. Keller et al. 13355 (CTES, OXF). BRAZIL. Bahia: Rod. Br-020, $10 \mathrm{~km} \mathrm{~N}$ de Barreiras, 12 March 1979, G. Hatschbach 42084 (CTES, FTG). Goiás: São Domingos, $13^{\circ} 31^{\prime} 25^{\prime \prime} \mathrm{S} 46^{\circ} 26^{\prime} 46^{\prime \prime} \mathrm{W}, 579 \mathrm{~m}, 9$ March 2004, A. A. Santos 2197 (CEN). Maranhão: km 63, Mun. Estreito, Estreito Maranhão-San Pedro dos
Crentes, 6 $51^{\prime} 07^{\prime \prime S} 47^{\circ} 01^{\prime} \mathrm{W}, 350 \mathrm{~m}, 9$ Jan. 2008, G. Pereira-Silva $\mathcal{E}$ G. A. Moreira 12442 (CEN). Mato Grosso do Sul, 68 km W of Jardim, 27 June 1977, fr., A. Krapovickas $\mathcal{E}$ A. Schinini 32751(CTES). Minas Gerais: Ituiutaba, São Vicente, 16 Oct. 1943, A. Macedo 86 (K, US); ibid., Faz. Terezinha, 13 Feb. 1949, A. Macedo 1666 (MO, RB); Mun. Ituiutaba, Aroeíra, 12 Jan 1956, A. Macedo 4141 (BM); sin. data, 400 - 500 m, A. Macedo s.n. (LIL331196). Tocantins: BR 230, Trans-Amazonian highway, $6 \mathrm{~km} \mathrm{~W}$ of Estreito, 6 ${ }^{\circ} 32^{\prime} \mathrm{S} 47^{\circ} 32^{\prime} \mathrm{W}, 300 \mathrm{~m}, 28 \mathrm{Feb} .1980$, T. Plowman et al. 9277 (MG, MO, NY, RB); Mun. Tocantinopolis, km 18 estrada vecinal á Ferrovia Norte Sul, 6 $38^{\prime} 50^{\prime \prime} \mathrm{N} 47^{\circ} 29^{\prime} 56 \mathrm{~W}, 190 \mathrm{~m}, 21$ Feb. 2005, G. Pereira-Silva et al. 9483 (holotype CEN); Palmeiras do Tocantins, estrado do Rio Curicaca, a partir da BR153, 6³8'46"S 47³3'59"W, 200 m, 12 Jan. 2008, G. Pereira-Silva E G. A. Moreira 12546 (CEN).

CONSERVATION STATUS. This species is recorded over a wide area of central Brazil from five different states and from Misiones Province in NE Argentina so it would appear to be of Least Concern, although records are not very numerous. However the cerrado biome is under threat from conversion to pasture, competition from invasive African grasses, soya cultivation and, in recent years, to the production of biofuels. As all records of Ipomoea aequiloba appear to be from low altitude, presumably vulnerable cerrados, 
the status of this species needs to be carefully evaluated to assess whether it is under any threat. For the moment it should be classified as Data Deficient (DD).

EPONYMY. The epithet aequiloba refers to the apparently 3-lobed leaves in which the auricles equal the blade.

\section{Acknowledgements}

John Wood and Robert Scotland acknowledge the financial support of the Leverhulme Trust in funding their monographic work on Ipomoea and also acknowledge an NERC IAA award to fund the illustrations. We are grateful to Rosemary Wise for preparing the line drawings. We have had useful discussions with Stephen Harris about Gardner's itinerary and with Nick Turland over typification issues. We are grateful to all the curators who have assisted John Wood during his visits to the herbaria at ARIZ, BM, CEN, CTES, IPA, MBM, MO, NY, P, R, RB and $\mathrm{SP}$ where important specimens were seen and/or from where we have received very useful loans. Moises Mendoza also provided useful images of specimens at CEN and Hector Keller showed John Wood Ipomoea aequiloba in the field in Argentina. Kew (K) and Geneva (G) are also thanked for the provision of images, which have helped resolve various problems.

Open Access This article is distributed under the terms of the Creative Commons Attribution 4.0 International License (http://creativecommons.org/ licenses/by/4.0/), which permits unrestricted use, distribution, and reproduction in any medium, provided you give appropriate credit to the original author(s) and the source, provide a link to the Creative Commons license, and indicate if changes were made.

\section{References}

Austin, D. F. (1981). Novidades nas Convolvulaceae da flora amazónica. Acta Amazonica 11(2): 291 295.

(1982a). Fam. 165. Convolvulaceae. In: G. Harling \& B. Sparre (eds), Flora of Ecuador Vol. 15. Department of Systematic Botany, University of Götenberg and the Section for Botany, Riksmuseum, Stockholm.

(1982b). Convolvulaceae. In: Flora of Venezuela 8: Fundación Instituto Botánico de Venezuela. (1998). Convolvulaceae. In: J. A. Steyermark, P. E. Berry \& B. K. Holst (eds), Flora of the Venezuelan Guayana 4: 377 - 423. Missouri Botanical Garden Press, St Louis.
\& Simão-Bianchini, R. (1998). Additions and corrections in American Ipomoea (Convolvulaceae). Taxon 47: 833 - 838 .

, Staples, G. W. \& Simão-Bianchini, R. (2015). A synopsis of Ipomoea (Convolvulaceae) in the Americas: Further corrections, changes, and additions. Taxon 64 (3): 625 - 633.

Chodat, R. \& Hassler, E. (1905). Plantae Hasslerianae. Bull. Herb. Boissier, Ser. 2, 5. 671 - 699.

Choisy, J. D. (1845). Convolvulaceae. In: A. de Candolle (ed.), Prodromus Systematis Naturalis 9: 323 - 462. Fortin, Masson \& Co, Paris.

Dietrich, A. (1836). Beschreibung der Ipomoea elegans nobis einen neue Zierpflanze aus Brasilien. Allg. Gartenzeitung [Otto \& Dietrich] 4 (38): 313 - 314.

Don, G. (1838). A general history of the dichlamydeous plants, Vol. 4. C. J. G. \& F. Rivington, London.

Dubs, B. (1998). Prodromus Florae Matogrossensis. Betrona-Verlag, Küsnacht.

Gardner, G. (1842). Ipomoea (Strophipomoea) goyazensis Gardn. Icon. Pl. t. 479.

Glaziou, A. F. M. (1910). Liste des Plantes du Brésil central. Bull Soc. Bot. France 57, mémoire 3e: 393 - 488.

Flora do Brasil 2020 em construção. Jardim Botânico do Rio de Janeiro. Available at: <http:// floradobrasil.jbrj.gov.br/reflora/floradobrasil/ FB7021>, accessed on 19 April 2016.

Hallier, H. (1899). Convolvulaceae. In: R. Chodat \& E. Hassler, Plantae Hasslerianae. Bull. Herb. Boissier 7, App. 1: $43-87$.

Hassler, E. (1917). Addenda ad Plantas Hasslerianus. Kundig, Geneva.

Hooker, W. J. (1844). Ipomoea crassipes. Bot. Mag. t. 4068.

IUCN (2012). Guidelines for application of IUCN Red List Criteria at Regional and National Levels. International Union for the Conservation of Nature, Gland.

Jacquin, N. J. (1790 [publ. 1791]). Collectanea, Vol. 4. Wappler, Vindabonae (Vienna).

Meisner, C. F. (1869). Convolvulus. In: C. Martius, Flora Brasiliensis 7: 200 - 424. Fleischer, Leipzig.

Meeuse, A. D. L. (1958 [1957]). The South African Convolvulaceae. Bothalia 6: 641 - 792.

O'Donell, C. A. (1948). Convolvulaceas Argentinas y Paraguayas nuevas o críticas. Lilloa 14: 169 - 192. (1950a). Convolvulaceas Americanas Nuevas o Criticas 1. Lilloa 23: 421 - 456. (1950b). Convolvulaceas Americanas Nuevas o Criticas 2. Lilloa 23: 457 - 509. (1952). Convolvulaceas Americanas Nuevas o Criticas 3. Arq. Mus. Paranaense Curitiba 9: 207 - 244. (1953). Convolvulaceas Americanas Nuevas o Criticas 4. Lilloa 26: 353 - 400. (1959a). Las especies americanas de Ipomoea L. sect. Quamoclit (Moench.) Griseb. Lilloa 29: 19 - 86. (1959b). Convolvuláceas argentinas. Lilloa 29: 87 $-348$. 
(1960). Notas sobre Convolvulaceas Americanas. Lilloa 30: 39 - 69.

Rafinesque, C. S. (1838). Flora telluriana, Vol. 4. Philadelphia.

Ramella, L. (2010). Catalogus Hasslerianus 3. In: L. Ramella \& P. Perret (eds), Flora del Paraguay, Serie especial 6. Conservatoire et Jardins Botaniques de la ville de Genève.

Simão-Bianchini, R. \& Ferreyra, P. P. A. (2010). Convolvulaceae. In: Catálogo de Plantas Fungos do Brasil 2: 882 - 894 .
Sims, J. (1826). Ipomoea bignonioides. Bot. Mag. 53: t. 2645.

Sprengel, C. K. (1827). Systema Vegetabilium, ed, 16, 4 (2): 1 - 410. Dietrich, Göttingen.

Taubert, P. (1895). Beiträge zur Kenntnis der Flora des centralbrasilianischen Staates Goyaz. Bot. Jahrb. Syst. 21: $402-457$.

Wood, J. R. I., Carine, M. A., Harris, D., Wilkin, P., Williams, B. \& Scotland, R. W. (2015). Ipomoea (Convolvulaceae) in Bolivia. Kew Bull. 70: 31, 1 124. 